\title{
GLOBALIZÁCIÓ ÉS TÉRSÉGI FEJLŐDÉS
}

\author{
(Globalisation and Regional Development)
}

\author{
SZIRMAI VIKTÓRIA - BARÁTH GABRIELLA - \\ MOLNÁR BALÁZS - SZÉPVÖLGYI ÁKOS
}

\begin{abstract}
Kulcsszavak:
globalizäció multinacionális vállalkozások társadalmi-gazdasági integráció Székesfehérvár

Az utóbbi néhány év világgazdasági történései a magyar szakemberek figyelmét is a globalizáció folyamatai felé forditották. A globalizáció esetén legtöbbször azonban csak annak gazdasági oldalairol beszélïnk, miközben nem, vagy alig ejtïnk szót a tärsadalmi, a politikai és a kulturális hatásokrôl. Ezért ebben at tanulmányban a globalizáció konkrét térségi társadalmi és gazdasági hatásainak feltárására vállalkozunk. Egy székesfehérvári empirikus kutatás eredményei alapján - és természetesen számos egyéb, hasonló típusú konkrét vizsgálat által feltártak szerint - kísérletet teszünk a globalizáció helyi folyamatainak elfogulatlan elemzésére, a térség fejlödése szempontjából kedvezō és kedvezôtlen következmények tisztázására.
\end{abstract}

\section{Bevezetés}

A kelet-közép-európai térségben megvalósult átmenet legsikeresebb települései és régiói a külföldi tőkebefektetések, vagyis a globális gazdaságba való beilleszkedés szerint indultak fejlődésnek, oldották meg korábbi válságaikat. A továbblépés lehetóségei azonban - a globális gazdaság egyre ellentmondásosabb hatásai miatt - igen kétségesnek látszanak. A fejlettebb térségekben, illetve településeken ma az egyik legidőszerủbb probléma a fenntarthatóság biztosítása, az elért gazdasági fejlődés szinten tartása, esetleg nỏvelése, a „hogyan tovább?” kérdése. Ezekben a térségekben az a kérdés is felmerül, hogy lehet-e, illetve kell-e a globális gazdaság törvényei szerint tovább fejlődni? Meg lehet-e örizni az elért szintet, vagy változtatni kell, más utakat és más modelleket kell keresni? Egyáltalán vannak-e más utak?

A fejletlenebb térségek, a fejlettek perifériái, a hátrányosabb helyzetü mikrorégiók számára azonban másképp merül fel a jỏvőbeni fejlődés problematikája. Nekik azt kell eldönteniük, hogy milyen stratégiát kövessenek? Kövessék-e a fejlettebb térségekben, és településeken kialakult modelleket, vegyék-e tudomásul az ott kialakult társadalmi és gazdasági veszélyeket, vagy más utat válasszanak? Van-e egyáltalán választási lehetőségük?

Olyan, a tanulmány lehetőségeit természetesen meghaladó kérdésekről van szó, ahol a válaszok a legkülönbözöbb szakmacsoportok egyuittmüködését, számos kutatást, elfogulatlan elemzéseket feltételeznek. Már vannak ilyenek. Az utóbbi néhány év világgazdasági történései a magyar szakemberek figyelmét is a globalizáció felé fordították. A megnőtt érdeklődést mutatja, hogy egyre több ůj könyv jelenik meg, baloldali, jobboldali kritikai nézöpontok csapnak össze (Farkas 2002). Sokasodnak 
Tér és Társadalom, 17. 2003. 3. 29-57. $p$.

30 Szirmai V.-Baráth G.-Molnár B.-Szépvölgyi Á.

TÉT XVII. évf. 2003

a globalizáció témaköreiben megrendezett szakmai jellegü, tudományos konferenciák, empirikus vizsgálatok is.

Az új elemzések, az elfogulatlan kutatások igen fontosak. Ennek alapján lesz mód a globalizáció differenciált természetének megismerésére. A nemzetköziesedés folyamatának minden elemét ugyanis nem ismerjük. Igen sokan állítják viszont, hogy a globalizáció más, mint az összes, azt megelöző világméretủ folyamat volt, hatásai most bontakoznak ki, most érzékelhetők igazán. A világgazdaság történetében elöször bontakozik ki ugyanis a világ egészére kiterjedő, az amerikai gazdasági hegemóniát felváltó többpólusú gazdasági rendszer, amelyet már nemcsak a világkereskedelem bỏvülése, hanem mindinkább a töke, a beruházások, a fejlett technológia, a tudományos kutatás, az oktatás és a tudás mind eröteljesebb nemzetközivé válása határoz meg. Emellett a nemzetközi kapcsolatokban egyre nagyobb súllyal szerepelnek olyan globális kérdések is, mint a környezetrombolás, az ökológiai egyensúly megbomlása, a demográfiai robbanás vagy a közjavak használatának összehangolása és szabályozása (Surányi 1999; Inotai 2001).

A globalizáció esetén legtöbbször azonban csak annak gazdasági oldalairól beszélünk, miközben nem, vagy alig ejtünk szót a társadalmi, a politikai és a kulturális hatásokról. Noha a globalizáció elsősorban nem is gazdasági folyamat (Inotai 2001). Nem tisztáztuk a globális folyamatok gazdasági és társadalmi összefüggéseit, valamint politikai, hatalmi következményeit sem (Lányi 2001). Pedig ezek is nélkülözhetetlenek a jövő stratégiáinak kijelöléséhez.

Ebben a tanulmányban a globalizáció konkrét térségi társadalmi és gazdasági hatásainak feltárására vállalkozunk. Egy székesfehérvári empirikus kutatás eredményei alapján - és természetesen számos egyéb, hasonló típusú konkrét vizsgálat által feltártak szerint - kísérletet teszünk a globalizáció helyi folyamatainak elfogulatlan elemezésére, a térség fejlődése szempontjából kedvező és kedvezőtlen következmények tisztázására. Megvizsgáljuk azt is, hogy az érintett elitcsoportok milyen szerepet töltöttek be a térségi globalizáció megvalósulásában. Továbbá, hogy ez a szerep hogyan, milyen szempontok szerint változik. Reményeink szerint a feltárt folyamatok alapján javulhatnak a globalizációs problémák kivédésének lehetőségei és a „hogyan tovább?" kérdésekre adott válaszok kimunkálásának feltételei.

\section{A globalizáció hatásai}

A nemzetközi sajtóból, a médiából, az idegen nyelvủ szakkönyvekböl már hosszú évek óta információkhoz lehet jutni - a legkülönbözőbb fejlettségi szintủ országokban - egyes telephelyeiket bezáró, vagy éppen az országokat elhagyó, máshová telepedő transznacionális, illetve multinacionális vállalatokról és ennek kedvezőtlen gazdasági, társadalmi hatásairól. Ezek közül kiemelten fontosak az érintett térségek gazdaságát ért károk, az alkalmazottak - a vállalatok méretétôl és típusától függó létszámban történő - elbocsátása és az ebböl is adódó társadalmi feszültségek.

A legnagyobb transznacionális cégek vezetó topmenedzsereinek 1995-ös találkozóján elhangzottak szerint ,az elkövetkező évszázadban a munkaképes lakosság 
Tér és Társadalom, 17. 2003. 3. 29-57. p.

húsz százaléka elég lesz ahhoz, hogy lendületben tartsa a világgazdaságot" (Martin-Schumann 1998). Szakmai értékelések tömege kritizálta és finomította már ezt, de szerintük is a világgazdasági folyamatok jövőbeni alakulásából növekvő munkanélküliség, és ebből is adódóan a szegénység kiterjedése, elmélyülése várható. További súlyos probléma, hogy a globális töke ma már nemcsak a gazdaságot, hanem az államot és a társadalmi életet is egyre inkább irányítja (Willkinson-Hughes 2002). Szintén sokan kritizálják a globalizáció által közvetített életformák és kultúrák, fogyasztási szokások agresszív, egyben társadalmi homogenizáló hatásait, valamint a nemzeti és lokális kultúrák visszaszorulását (Hay-Marsh 2000).

Az 1990-es években a világ szinte minden régiójában felerősödtek a globalizációellenes társadalmi megmozdulások. A globalizáció társadalmi-gazdasági igazságtalanságai, a környezeti ártalmak ellen tiltakozók, a különbözó új mozgalmak szerveződése - az úgynevezett anti-globalista, anti-kapitalista, illetve globalizáció kritikai csoportok - társadalmi és politikai szempontból, a globális gazdasághoz füződő viszonyuk, valamint baloldali vagy jobboldali beállítottságuk szerint is igen differenciáltak. Középosztálybeli, vagy munkás jellegük alapján társadalmi összetételük és támogatottságuk szintén eltérő (Farkas 2002; Artner 2003). A tiltakozások, megmozdulások számának emelkedése a globalizáció kárvallottjaj létszámának és társadalmi érdekérvényesítési képességének növekedésére utal. Az elutasítás pedig kiváltja végül azt az eredményt, hogy a helyi terület, a lokalitás megerösödik, a két irányultság egymásra hatása növekszik, illetve maguk biztosítják és tartják egyben fent a kettösséget, hogy a fragmentálódás továbbra is ikertestvére maradhasson a globalizációnak (Bauman 1998).

\section{Az elitcsoportok szerepe}

Kelet-Közép-Európában, közte Magyarországon azonban igen alacsony a globalizáció ellenes társadalmi mozgalmak támogatottsága, részben a tiltakozási kultúra és a történeti meghatározottságok, részben pedig a múlt század 1980-as évek végének térségi kényszerpályái miatt. A kelet-közép-európai országok történetileg kialakult strukturális, gazdasági és társadalmi válsága enyhítésének feltételeit a globális gazdasághoz csatlakozás körülményei teremtették meg. Noha ebben a régióban, Magyarországon is érzékelhetők a globalizációs problémák - például a multinacionális, transznacionális cégek kivonulásával kapcsolatos gondok -, azokat az országos és helyi elit, bár egyre nehezebben, de még képes kezelni (bár a legutóbbi idöszakban is találunk példát arra, hogy az embertelen munkakörülmények és az alacsony bérek miatt a multinacionális cégek dolgozói sztrájkot hirdetnek. Ilyen munkabeszüntetés történt 2003 júljusában az ászári ITW Siewer üzemében.)

Az elitcsoportok azonban nagyon ellentmondásosan élték meg a világméretủ folyamatok hazai térnyerését. Különböző szociológiai kutatások szerint az 1980-as évek végén, 1990-es évek elején az elitcsoportok egyértelmüen támogatták a globális fejlődési folyamatokat - mely része volt a politikai rendszerváltásnak és a polgári átmenet kibontakozásának -, miközben már akkor is voltak, akik a kedvezőtlen 
Tér és Társadalom, 17. 2003. 3. 29-57. p.

hatások miatt alapvetöen elutasították azokat (Szirmai 1994). Ezek a hangok azonban kisebbségben maradtak. Az újabb empirikus kutatások szerint azonban ma már növekedni látszanak a globális folyamatokat kritikailag szemlélö társadalmi és szakmai csoportok (Szirmai-A. Gergely-Baráth-Molnár-Szépvölgyi 2002).

Számos oka van a kritikai szemlélet növekedésének. Egyrészt történelmi meghatározottságok, másrészt az államszocialista rendszerben kialakult társadalmi szerkezeti sajátosságok, az egyenlőség-eszme, amely alapján sokan vitatják a globalizáció pozitív hatásainak kizárólagosságát. Az államszocialista hatalom a társadalmi ideológiai illúziókat sokáig és számos eszközzel védte. Miközben a fejlett piaci társadalmaknál szokásoshoz képest ebben a régióban valóban enyhébb társadalmi és gazdasági egyenlőtlenségek jöttek létre. A rendszerváltó elit szocializációs folyamatai, de legfőképpen a társadalmi értékrend szerint nem könnyü elfogadni sem a kemény egyenlötlenségekben szerveződő globális gazdasági folyamatok hierarchikus jellegét, sem a hatalmi kiszorítottságot (Csite-Kovách 1998). Szintén nem könnyủ megtalálni ebben az önállóságot - néha persze annak csak látszatát - sem. A relatív függetlenség kivívása is nehezebbnek tủnik, mint a meglévő elfogadása. Ezért sokszor csak a kritika válik központi céllá, miközben az elönyök feltárása és adaptálása elmarad.

Az ellenérzéseket növeli, hogy a korábbi szovjet és államszocialista modelltől ugyan eltérö, új típusú, de mindenképpen új függéseket okozó berendezkedés szervezödésének vagyunk tanúi (gazdasági, politikai, szervezeti, területi stb.), s az átmenet elején ezek a függések nem voltak világosak (Kovách 1997). Az elitcsoportok mellett az érintett társadalmak is most kénytelenek szembenézni a globalizáció kedvezö és kedvezötlen következményeivel, a korábbi eredményekkel, illetve az azokból is fakadó konfliktusok veszélyeivel.

A kritikákban megfogalmazott feszültségek reális elemzését, a kedvezötlen hatások megfogalmazását persze megnehezítik a kivívott eredmények, a polgári berendezkedés elönyei, a demokrácia, a nyitott világ, a globális gazdaságba csatlakozás pozitív következményei, valamint a gazdasági válság enyhülése, a növekvő jólét és a térségek fejlödése. Vagyis mindaz, amit az átalakulás, ezen belül a globalizációs hatások a társadalom számára - tegyük hozzá igen nagy ellentmondásokban - nyújtanak.

A kelet-közép-európai elitcsoportok a globalizációt, a rendszerváltást és a polgári átmenetet egyrészt alapvetôen elfogadták - még ha kritikailag is szemlélték -, másrészt meg is valósították, valósítják azt. A szóban forgó szereplők az éles gazdasági válság periódusában fontos szerepet játszottak a globális gazdasághoz történö csatlakozásban. E csoportok részvétele nélkül talán soha, vagy legalábbis csak nagyon nehezen jöttek volna létre a globális gazdasági, illetve térségfejlödési folyamatok. Ez akkor is igaz, ha tudjuk, hogy az átmenet elején kialakult súlyos gazdasági helyzet, az eladósodás ,kényszerítö körülményekként” határozták meg a külföldi müködö töke politikai elfogadását (Barta 2002). Egyrészt nem akadályozták - még ha egyes szakmacsoportok kismértékben vitatták is -, másrészt szervezeti, szakmai, kulturális és ideológiai érdekeik szerint alapvetően támogatták is. Ebben az idöszakban szinte teljesen hiányzott a mérlegelés, az elönyök és a hátrányok mindenki 
Tér és Társadalom, 17. 2003. 3. 29-57. p.

számára nyilvánvaló, egyértelmü értékelése. Hiányzott a globalizáció társadalmi kommunikációja is (többek között azért is, mert akkor kiderült volna a hazai elitcsoportok szűkülő mozgástere, nyilvánvalóvá vált volna, hogy a globális folyamatok hatására csökken a nemzeti politikai és gazdasági befolyás), illetve hiányoztak a védekezés, a kezelés eszközei, és az azokat megalapozó koncepciók is.

Az 1990-es évek derekától érzékelhető folyamatok alapján azonban az elitcsoportok új szerepére van szükség. Az új szerepet az új helyzet és az azt megalapozó folyamatok indokolják. Az átmenet alapvetően végbement, a magyar társadalom az európai trendeknek megfelelően fejlődik, a gazdasági válság enyhült, számos térség dinamikus fejlödést mutat. Az európai integrációval, az európai uniós tagsággal hosszú távon javulhat Magyarország pozíciója, és vélhetöen csökkenthetök lesznek az 1990-es években még kényszerünek tünő függések. Egyre többen látják és láttatják a tényleges hatásokat, csökkentek az illúziók is. Nő azoknak a száma, akik érezni szeretnék a tényleges mozgástereket, akik nem passzívan, hanem aktívan is részt akarnak venni a globalizáció - felfogásunk szerint szükségszerü, de remélhetöen irányítható - folyamataiban, ezzel is enyhítve az esetleges kedvezötlen következményeket. A tanulmányt megalapozó kutatás is ennek az igénynek a jegyében született.

\section{Az empirikus kutatás háttere}

\section{A székesfehérvári vizsgálat}

Székesfehérvár térségében is érzékelhetök a globalizációra jellemzö ellentmondásos következmények, a pozitív és negatív hatások egyidejüsége. Az 1980-as évek végén felerősödött térségi gazdasági válság a globális gazdaság hatásmechanizmusainak köszönhetően is enyhült, a „székesfehérvári sikertörténetként” elkönyvelt, az 1990-es évektöl érzékelhető gazdasági fellendülés legjelentősebb forrását a külföldi tőkebefektetések eredményei adták. Ezzel párhuzamosan az elmúlt néhány évben kedvezötlen gazdasági hatások is megfigyelhetők a térségben, amelynek első konkrét jele a Mannesmann 2001-es távozása volt Sárbogárdról. További kedvezötlen jeleket mutatnak a 2002-es év eseményei, az IBM és a Kenwood kivonulása, a Videoton és az Ikarus leépítései is. Ezek az események részben konkrét - azonnali beavatkozást igénylö - társadalmi problémákat eredményeztek, részben az érintett önkormányzatok részéről felvetették a térségi gazdaságfejlődés hosszú távú fenntarthatóságának kérdéseit, és az ezt megalapozó kutatások szükségességét is.

Székesfehérvár Megyei Jogú Város és Fejér Megye Önkormányzata megbízására az MTA RKK NYUTI Közép-dunántúli Kutatócsoportja empirikus kutatást végzett a globalizáció térségi hatásairól, ezen belül a multinacionális cégek telephelyválasztási stratégiáiról Székesfehérváron, illetve Fejér megyében. A vizsgálatban a komplex problémakör néhány fontos metszetének feltárására törekedtünk. Egyrészt a gazdasági életben lejátszódó globalizáció bizonyos vonatkozásait, a multinacionális cégek telephelyválasztási stratégiáit, lokális gazdasági kapcsolatrendszereit, a térségi, a gazdasági és a társadalmi fejlődésre gyakorolt hatásaikat 
Tér és Társadalom, 17. 2003. 3. 29-57. p.

elemeztük. Másrészt a multinacionális cégek és a városi társadalom - lehetőségeink szerint föként az elit csoportok - viszonyának, a globális és a lokális integráció egyes folyamatainak feltárására vállalkoztunk. ${ }^{1}$

\section{A globális és a lokális viszonya}

A hazai szakirodalom szerint a térségi és a városi gazdaság fejlődése számára rendkívül fontos a külföldi vállalatok lokális beágyazottsága. Ennek révén jobban integrálódik a tőke, illetve ez biztosíthatja a magyar vállalatok hosszú távú fejlödését (Barta 2002). Ez a beágyazottság azért is lényeges, mert a globális és a lokális folyamatok, a folyamatokat reprezentáló gazdasági és társadalmi erök viszonya hosszú távon meghatározzák a globalizáció jellegzetességeit, konkrét hatásmechanizmusait és a lokális érdekek érvényesülését.

A hazai szakirodalom egy részében a multinacionális vállalatok ,szigetként”, „zárványként” jelennek meg, a globális és a lokális gazdaság sokkal inkább szakadékaiban, mintsem kapcsolataiban kerül vizsgálat alá (Szalai 2001). A gazdasági elemzések a kialakult helyzetet a magyar gazdaság viszonylag fejletlen színvonalával, müszaki elmaradottságával és a külföldi müködő tőke rövid történeti múltjával magyarázzák (Barta 2002).

A multinacionális cégek szigetszerủ létezését a szakirodalom szerint több tényező is mutatja: a vállalatok és a beszállítók korlátozott kapcsolatai, a multinacionális cégek többnyire külföldi beszállítókkal alakuló együttmüködései és a termékek exportálása (Szalai 2001). Kevesebb és gyengébb szálakkal kapcsolódnak a hazai gazdasági szektorokhoz, s kiemelt támogatásaiknak köszönhetően sokkal kevésbé is hatnak rájuk a belpiaci események, mint a többi vállalkozásra (legtöbbször belső kereskedelmük nagyobb, mint a hazai piaci értékesítesük). Kellően tőkeerösek ahhoz, hogy a konjunktúra hatásait kivédjék, így hosszabb távon is képesek tervezni: sokszor még dekonjunktúra idején is fejlesztenek, terjeszkednek, így is előkészülve a késöbbi ,jobb idökre”, illetve piacot foglalnak, vagy csak „,megdolgozzák” azt (Molnár-Skultéty 1999).

A szigetszerủ felfogást képviselő kutatások is beszámolnak azonban integrációs jelenségekröl (bár alapvetően negatív kontextusban). Szalai könyvében például olvashatunk olyan multinacionális cég filozófiákról, amelyek a helyi, a nemzeti társadalmak előrelépését, fejlődését akarják támogatni. Találunk példákat ,üzleti, hatalmi érdekek által motivált” szociális érzékenységröl is, ezzel kapcsolatos küldetéstudatról, de konkrét szponzorálásról, különböző típusú társadalmi kapcsolatokról is (Szalai 2001, 118-124).

A fent jelzett vagy ahhoz hasonló integrációs jellegü törekvések csak meghatározott kontextusban értékelhetök. A történeti visszatekintés alapján ezeket elörelépésként is értékelhetjük. Különösképpen akkor, ha arra gondolunk, hogy a múlt század közepén a transznacionális cégek a verseny szempontjai alapján egyértelmüen elutasították a vállalatok szociális elkötelezettségét, és azt a civil társadalmi szervezetek, lakóhelyi közösségek feladataiként fogták fel (Martin-Schumann 1998). A 
Tér és Társadalom, 17. 2003. 3. 29-57. p.

kilencvenes évek végének magyarországi és nemzetközi kutatásai szerint azonban a multinacionális cégek versenyképességük javulását már egyértelműen összekapcsolták belső jóléti rendszereik megteremtésével (Simonyi 2000, 33).

Az integráció kialakulásának a szempontjait más hazai kutatások is érzékelik. Ezek szerint a befektetők - saját üzleti céljaik érdekében - a Magyarországon tapasztalható intellektuális elönyök, a szellemi tỏke vállalati felhasználása miatt fokozatosan megerósítik helyi kapcsolataikat (Makó-Ellingstad 1999).

Véleményünk szerint a globális-lokális viszony, illetve az integráció attól is függ, hogy mennyire globalizált egy tér, egy város, milyen mértékben és milyen hatalmi viszonyok alapján kapcsolódnak az adott térben élök, a különböző státuszcsoportok a globális gazdaság folyamataihoz, milyen arányban és milyen érdekérvényesítési pozícióban vannak jelen a globális és a lokális gazdasági, társadalmi erők.

A Sassen által elemzett globális városok viszonyaival való egybevetés esetén teljesen természetes (Sassen 1991), hogy a magyar városok a globalizáció mértékének megfelelően reprezentálják a globális folyamatokat és azok képviselóit, illetve integrációs igényeit is. Székesfehérvár, Győr, Tatabánya, de még Budapest is sokkal inkább lokális, mintsem globális társadalom, illetve város. Ennek alapján, Budapesten erőteljesebben, míg Győrben, Székesfehérváron vagy Tatabányán kisebb mértékben jelennek meg a globális hatások és azok reprezentánsai, akik eltérően használják a helyi teret, a szolgáltatásokat, és eltérỏ módon vesznek részt a helyi társadalmi és közéletben is. A differenciáltság oka alapvetỏen kettős: egyrészt a vizsgált tér globális struktúrában elfoglalt eltérö helyzete, másrészt az eltérỏ városi kínálat, a szolgáltatások, az építészeti, urbanisztikai és kereskedelmi feltételek különbségei miatt alakult ki.

A térhasználatnál is fontosabbak a teret alakító érdekviszonyok, a globális és a lokális szereplök hatalmi, érdekérvényesítési és várospolitikai beleszólási lehetőségei. A vonatkozó szakirodalom szerint ez utóbbi az országos politikán és sajtón keresztül érvényesül leginkább (Kolosi-Szelényi I.-Szelényi Sz.-Western 1991; Szalai 2001). Saját empirikus tapasztalataink szerint ez regionálisan és városokként is differenciált. Az aktív, önálló várospolitikára törekvő önkormányzatok saját globális politikákat alakítanak ki, és esetleg közvetlen kapcsolatban állnak a külföldi vállalatok vezetőivel is. A globális és lokális társadalom közötti integráció a döntésmechanizmusoktól, a globális és lokális aktorok részvételi lehetőségeitől is függ. Vélhető, hogy azokban a városokban, ahol a multinacionális cégeknek jók a város vezetöivel kialakított kapcsolataik, ahol mód van közös döntésekre, ott erősebbek a társadalmi, közéleti, politikai és a mindennapi integrációs folyamatok is (SzirmaiA. Gergely-Baráth-Molnár-Szépvölgyi 2002).

Korábbi kutatásaink alapján is úgy véljük, túlzottan leegyszerüsített a szigetszerủ felfogás: az 1990-es évek második felének folyamatai új tendenciákat, a globális és a lokális aktorok új viszonyát is ígérik. ${ }^{2}$ Ezért a székesfehérvári kutatás keretében abból indultunk ki, hogy a globalizációs hatások - ezen belül akár a pozitív, akár a negatív társadalmi-gazdasági kővetkezmények -, és azok arányai is döntő mértékben függenek a befogadó - nemzeti, regionális, térségi, lokális stb. - közeg és a 
Tér és Társadalom, 17. 2003. 3. 29-57. p.

globális viszonyától, a globális-lokális viszonyrendszerektöl, kölcsönhatásoktól. Értelmezésünkben a globalizáció nem csupán egy kívülröl érkezö, a lokális szereplökre erőszakolt, egyben passzivitást feltételező folyamat, hanem a globális és lokális mechanizmusok interakciójában, a globális és lokális aktorok kölcsönös kapcsolatrendszerében és kommunikációjában szerveződö, történetileg változó rendszer (Szirmai-Baráth-Molnár-Szépvölgyi 2002).

Feltevésünk szerint lényeges és kölcsönös, időben változó mértékủ függések és autonóm kapcsolati hálók mutathatók ki a globális gazdaság - ezen belül az adott vizsgálatban a multinacionális cégeket, a globális gazdaságot és annak érdekeit képviselő szereplök - és a lokális társadalom között. A globális és lokális közötti függések és autonóm kapcsolati hálók nemzetközi és helyi tényezök szerint is alakulnak. A helyi tényezők szerepét a társadalmi részvételi mechanizmusok és a civil társadalom ereje, vagy leginkább gyengesége, valamint a különböző érdekelt vagy érintett aktorok közötti kooperáció is befolyásolja.

A kutatás feltevése szerint a hosszú távon fenntartható térségi gazdaságitársadalmi fejlödéshez szükségesek a globális hatások (ezen belül a multinacionális vállalatok jelenléte is), noha a különböző térbeli-történeti fejlödési szakaszokban jelentkező eltérések alapján formálódó sajátosságok szerint. Az államszocialista időszakból fakadó válságperiódus, az átmenet eleje, a globális gazdaságba történő integráció kezdeti szakasza erösebb globális függéseket okozott, míg a lezajlódó átmenet, a komplex társadalmi-gazdasági és politikai válság megoldása, a globális gazdaságba történő integráció, és az ebböl is következỏ térségi társadalmigazdasági fejlődés és jólét csökkentik a globális gazdaságtól való egyoldalú kiszolgáltatottságot, míg növelik a lokális aktorok részvételi lehetőségeit és autonómiáját.

A globális és lokális gazdasági és társadalmi kapcsolatok kölcsönösségére alapozott rendszer, a lokális gazdasági és társadalmi szereplök nagyobb szabadságfoka, az aktív részvétel a globalizációs mechanizmusok irányításában, kezelésében a térségi és városi versenyképességet is javítja, és a sikeres fejlődés lehetőségeit nyújtja.

\section{A kutatás föbb eredményei}

\section{A gazdaságfejlödési modell, a meghatározó folyamatok}

1) A székesfehérvári térség a külföldi tőkebefektetésekre alapozott térségi gazdaságfejlesztési modell szerint indult fejlődésnek. Az 1990-es évek elejére jellemző válság jelentős mértékben enyhült, a térség fejlődése dinamikussá vált. A gazdasági fejlödés hosszú ideig töretlennek látszott (annak ellenére, hogy a gazdasági szerkezet radikális változására nem került sor).

A külföldi tökebefektetésekre alapozott térségi gazdaságfejlesztési modell kialakulását a globális és lokális gazdasági erök - több hatótényezőben szerveződő és kibontakozó - közös érdekeltségei eredményezték. A közös érdekeltséget a keletközép-európai és a magyarországi átmenet keretében létrejött sajátos történelmi 
helyzet adta. Az 1990-es évek elejére Nyugat-Európában és az Egyesült Államokban a korábbi recesszió leküzdésével gyors gazdasági növekedés indult meg, amely a II. világháború utáni időszak leghosszabb növekedési periódusának bizonyult. A világgazdaság centrumtérségeinek sikerei pedig - éppen a piaci kapcsolatok megváltozó irányultsága miatt - kedvező feltételeket teremtettek a kelet-közép-európai országok gazdasági integrációjához is (Tamás 2001).

A külföldi müködőtőke-befektetés igényei, a multinacionális cégek kelet-középeurópai terjeszkedési politikái, a telephely-választási stratégiákat motiváló gazdasági, ezen belül a piacszerzésre irányuló tényezök ezeknek a folyamatoknak a meghatározó konkrét globális érdekei. A székesfehérvári térségi adottságok, a térség- és városfejlesztési politikák, és az ezeknek is kedvező társadalmi-gazdasági adottságok pedig a befogadást biztosító lokális feltételeket nyújtották. A társadalomszerkezeti és gazdasági átalakulás történeti sajátosságok, valamint a globális mechanizmusok szerint zajlott az államszocializmus válságából is adódó keretek által meghatározott módon (kritikus helyzetben lévő állami nagyipar, komoly térségi munkanélküliség, kezdetleges vállalkozói kultúra). Továbbá a bizonyos szempontokból kiemelkedő regionális, térségi és városi lehetöségek alapján (jó földrajzi elhelyezkedés, föváros-közelség, fejlett infrastruktúra, magas munka- és termelési kultúra, megfelelö szakképzettségü, alkalmazkodni képes munkaerö stb.).

A globalizáció mechanizmusai, a tulajdonviszonyok átalakítására, a privatizációra, a külföldi tőkebevonásra alapozott új fejlödési pálya alapvetően „mennyiségi” növekedést hozott. A mennyiségi növekedést jelzi, hogy Székesfehérvár - sikeresen kihasználva gazdaságfejlesztési és befektetés ösztönzési lehetőségeit - Györ után a legnagyobb magyarországi vidéki külföldi befektetöi területté vált. A befektetett külföldi működő tőke 2002-re elérte a 2 milliárd USD-t. A város 5 ipari parkjába több mint 475 ha területtel - több mint 140 cég telepedett le (nagy részük külföldi tulajdonú), és az egyes ipari parki címek elnyerése óta is több mint 500 milliárd forint összberuházás valósult meg bennük. A Közép-dunántúli régióban lévő ipari parkokba települt vállalkozások állítják elő a régió ipari termelésének csaknem negyedét, és összefogásuk, hálózati integrációjuk, hosszú távú együttmüködésük alapjainak a lerakása is megkezdődött és példaértékủ. Az elöző fejlesztéseknek is köszönhetően az 1993-ban még igen jelentös, 30\% körüli munkanélküliségi ráta az évtized végére 4-5\%-os értéken stabilizálodott. Ehhez kapcsolódott az infrastrukturális ellátottság fejlődése, a felsőoktatási kapacitások jelentős bővülése, illetve a mozgósítható fejlesztési források - az iparüzési adó kedvezmények miatt leginkább csak 2000-től jellemző - növekedése.

A mennyiségi nơvekedés azonban csak részben párosult „minőségi” fejlödéssel. A kialakult fejlödési pálya keretében nem jött létre a lakosság széles rétegeinek jóléte. Nem, vagy csak korlátozottan került sor a környezetvédelem, a térségi és városi társadalmi és kulturális élet, illetve kapcsolatok infrastrukturális és intézményes feltételeinek fejlődésére. A minőségi változások hiányát igazolja az is, hogy a felsőfokú képzési kínálat bővülése nem igazodott a munkaerö-kereslethez, vagyis elsösorban közgazdasági területen - jelentös túlképzés tapasztalható. Ennek ellené- 
Tér és Társadalom, 17. 2003. 3. 29-57. p.

re több területen érzékelhetök pozitív irányú minöségi változások, ilyen például a munkaképes korúak arányának növekedése (és ezzel párhuzamosan az eltartottak arányának csökkenése), illetve a múködö vállalkozások tevékenységének ágazati megoszlás-változása. Ennek megfelelően a Székesfehérváron mủködő vállalkozások súlya - számukat tekintve - az iparon belül a feldolgozóipar, míg a tercier szektoron belül az ingatlan- és gazdasági szolgáltatások, valamint a kereskedelem irányába tolódtak el. Ez a korábbinál lényegesen nagyobb hozzáadott értékủ, exportképes termékeket, illetve minőségileg javuló szolgáltatásokat eredményezett, vagyis növelte a város versenyképességét.

2) A gazdasági fejlődés folyamataiban a globális érdekek túlsúlya érvényesül, a globális és lokális gazdaság kapcsolatai a külföldi cégek érdekei szerint, de nem a lokális érdekek ellenében szerveződnek.

A multinacionális cégek gazdasági filozófiájának (egyetlen kivételtől eltekintve) célja, hogy helyi, regionális és országos együttmüködések alakuljanak ki. A kérdőívekre és a mélyinterjúkban adott válaszokból kitünik, hogy azonos (mintegy 30\%-os) arányt képvisel a helyi és országos együttmüködések kialakításának fontossága, ennél némileg kisebb súllyal szerepelnek viszont a regionális kapcsolatok (25\%). A cégek véleménye szerint ezek a kapcsolatok kialakultak.

A helyi aktorok véleménye azonban differenciáltabb. Eszerint vannak olyan transz- és multinacionális cégek a városban és a megyében, melyek vezetöi, menedzserei ma már magyarok, amelyek a termelésbe is egyre több magyar kis- és középvállalkozást vonnak be, és a gyártmányfejlesztést, egyes kutatási részlegeiket, marketingjüket, európai könyvelésüket, vagy egyéb, a termeléstöl eltérő szintet képviselö egységeiket is ide telepítették (pl. Denso, Visteon, Alcoa, Triumph stb.). Ezek célja egyértelmüen a ma még kezdetlegesnek mondható társadalmi-gazdasági integráció kiszélesítése. Mégpedig azért, hogy „tőkekomfort-érzésük” jobb legyen, hogy befektetéseiket biztonságban tudják, és gyorsabb legyen azok megtérülési rátája. Ebben az infrastruktúra árának minimalizálási igénye, a szolgáltatások könynyü és megfelelő szinten való elérhetősége és ára, a munkaerő biztonsága, képzettsége és olcsósága is benne van.

Míg azoknak a cégeknek, amelyek főleg szakképzetlen, betanított és segédmunkásokat (operátorok) nagy tömegben alkalmaznak, és/vagy a munkaerőt, illetve csarnokaikat bérlik, bizonytalan a vállalkozói és alkalmazotti légkörük, kevéssé törekednek a kis- és középvállalkozói kör szélesítésére. Ezek a cégek más részlegeiket jellemző módon nem telepítik ide, és a legkisebb lokális változásra is könnyedén kivonulással reagálnak. Ök csaknem mindent fő céljuk, a profit maximalizálása alá rendelnek és, ha azt veszélyek fenyegetik, negatív külső hatások érik, akkor is távoznak, ha azt világpiaci okokkal kevésbé lehet megindokolni (Szirmai-BaráthMolnár-Szépvölgyi 2002b).

A különböző újabb közgazdasági tanulmányok is a térségi gazdasági integrációval kapcsolatban azt rögzítik, hogy a magyarországi kis- és középvállalkozások zöme részben az eddigi vállalkozásfejlesztési programok hiányosságai miatt - versenyképesség tekintetében elmaradó, és általában alkalmatlan arra, hogy a külföldi nagy- 
Tér és Társadalom, 17. 2003. 3. 29-57. p.

vállalatoknak beszállítója Iegyen (Vilmányi 2000; Pálmai 2001; Deák 2002; Laki 2002; Kállay 2002; Lengyel 2002). A multinacionális cégekkel készített interjúink is részben megerösítették a vonatkozó kritikákat. A multinacionális cégek nehezen hajlandók a szigorú minőségi és hatékonysági elvárásaiknak nem megfelelö környékbeli, illetve magyar kis- és középvállalkozásokat igénybe venni. Beszerzéseik sokszor globálisan dölnek el (zömében az anyavállalati központban), a döntéseket pedig a minőség, megbízhatóság és a határidők pontos betartásának feltétele diktálja. A multinacionális vállalatok nagy része általában a korábban már jól bevált föként külföldi telephelyü - beszállítóit preferálja, esetleg a saját részlegeiben elöállított termékeket építi be, ezzel is növelve a profitáramlást (előbbire jó példa a Philips vagy a Ford [ma: Visteon], amely saját beszállítóit is hozta magával: a General Plastics-ot, illetve a Lorangert). De arra is van példa, hogy a már itt levő magyar, vagy - zömében - külföldi beszállítók vonzanak ide újabb külföldi multicégeket (pl. Brunswick).

Kivételt képeznek a más kontinensről származó multinacionális vállalatok, melyek egyik fontos célja, hogy európainak mutatva magukat, kedvezöbb feltételekkel exportálhassanak. Ezek motivációja és stratégiája alapvetően eltér az integrációval kapcsolatban is, hiszen létfontosságú számukra a nagyrészt magyar hozzáadott érték felmutatása az Európai Unióba történő könnyebb szállítások miatt (pl. Denso).

Általában már maga a termék el is dönti azt, hogy mely folyamatokba lehet a helyi kis- és középvállalkozói szektornak beszálítania. A legtöbb esetben a gyártási folyamatba például közvetlenül nem lehet beszállítani (hisz magának a külföldi cégnek is az a fö tevékenysége), ilyenkor leginkább a szerszámgépek elöállítását lehet megversenyeztetni (ha eleve nem úgy kapják őket bérbe, például a megrendelötöl). Összeszerelési tevékenységnél pedig az egyes alkatrészek - amennyiben szintén nem készen kapják a megrendelőtől -, illetve a gyártási folyamatokon kívüli munkarészek tekintetében már a legtöbb esetben most is helyi (de nem feltétlenül magyar érdekeltségú), vagy magyar (de nem feltétlenül helyi) cégek a beszállítók.

A korábban jelzett tendenciák, mely szerint a székesfehérvári és térségi multinacionális vállalatoknak a termelési folyamatba rendszeres beszállítói egyáltalán nincsenek, úgy tűnik azonban idővel némileg enyhülttek, bár az hosszabb távra is érvényesnek látszik, hogy a beszállítás leginkább nem szakmai területeken jellemzỏ és bövülő (Leveleki 1998; 1999). Az empirikus adatgyüjtésünkböl kiderült, hogy a térségi külföldi érdekeltségü cégek mindegyike kapcsolatban van országos szintú beszállítókkal, több mint 50\%-uk pedig a megyei besszállítói körrel is kialakított együttmüködéseket. Azt, hogy mekkora arányt képvisel a hazai és térségi beszállítói kör az egyes cégek teljes beszállítói körén belül, a megkérdezett cégek mindössze negyedrésze határozta meg (mindegyike esetén igen alacsony arány). Viszont a megkérdezettek minden esetben elégedettek voltak magyarországi beszállítóikkal.

A Fejér megyei kis- és középvállalkozói szektor körében készített mélyinterjúkból az derült ki, hogy sok esetben szerencsésnek érzik magukat, mert a korábbi magyar nagyvállalati struktúrából fennmaradt cégek most is jelen vannak a megyében (pl. Videoton, Ikarus, Köfém, Dunaferr, Dunapack). Ők ugyanis általában szerényebb 
Tér és Társadalom, 17. 2003. 3. 29-57. p.

40 Szirmai V.-Baráth G.-Molnár B.-Szépvölgyi Á.

TÉT XVII. évf. 2003

követelményeket támasztanak velük szemben, és könnyebben megteremtik az ugródeszkát számukra a későbbi „,mélyvízhez”, hiszen maguk is a kisebb beszállítói szektorból „nötték ki” magukat. Ma általában már integrátori funkciókat töltenek be, közvetítik a technológiai, minőségi és logisztikai követelményeket, és a térség specifikumaként magát a humán eröforrást is. A megyei kis- és középvállalkozások a külföldi cégek beszállítóiként biztos piacra tudtak és tudnak szert tenni, és fokozatosan sajátíthatnak el olyan eljárásokat, amelyek ma már technológiailag, minőségbiztosítási, szervezési, környezetvédelmi és más szempontokból is megfelelnek a megnövekedett elvárásoknak.

A kis- és középvállalkozói szektor hiányolja, és erőtlennek tartja azonban a kormányzat, a megye és a város különböző szervezeteinek azt a feladatát, hogy „saját eszközeikkel, kedvezményes hitelekkel, garanciákkal, támogatott képzésekkel, beszállitói konferenciákkal és katalógusokkal stb. segitsék elö a megerösödésünket, a beszállítói láncolat szemeinek összefogását". A helyi beszállítói kapcsolatok általában azért esetlegesek, mert a beszállítók nem fejlỏdnek megfelelően. A helyzetet tovább rontja, hogy például Kínában vagy Japánban ezek a helyi beszállítók igen gyorsan fejlődnek, így Magyarországon nem csak a beszállítók, hanem az ittlévő transz- és multinacionális vállalatok helyzete is nehezebbé válhat, ha ezen nem sikerül hatékonyan javítani. „Erre megoldás lehet a Japånban a Gazdasági, Kereskedelmi és Ipari Minisztériumon keresztül kialakított regionális termelési központok hálózata is, amely kimondottan a beszállitók fejlesztését, a termelékenységi szemlélet javítását célozza. Sajnos ez a szemlélet Magyarországon, de az Európai Unióban is hiányos." - hangzott el az egyik interjú keretében.

3) A gazdasági integrációt a multinacionális vállalatok és az önkormányzatok közötti kapcsolatok is befolyásolják. A multinacionális cégek képviselöivel készített interjúkban nagyobb arányt képviselnek a város vezetésével kialakított kapcsolatot eredményesnek értékelő vélemények. A megkérdezett cégek jelentös része stratégiai, az egyik legfontosabb partnernek tekinti a települési önkormányzatot. Fontosnak tartanák ugyanakkor, hogy az önkormányzat súlyuknak megfelelően kezelje a városban letelepült transz- és multinacionális vállalatokat.

A vállalatok képviselöivel készített interjúkban az önkormányzatokkal kapcsolatban negatív vélemények is megfogalmazódtak. Ezek közül az egyik - tipikusnak nem tekinthetö, de lényeges - vélemény szerint „a város vezetése az évtized elején meglehetősen jól állt a dolgokhoz, hatalmas energiákat mozgósított a multinacionális cégekkel kapcsolatban. Mára egyoldalúvá vált a dolog. Nem tapasztaljuk, hogy a város vezetése keresne minket".

A megkérdezett gazdaságfejlesztési és területfejlesztési szakértök álláspontjai is megerősítették a fenti véleményeket, hiszen fỏleg az évtized elején jellemző - kedvező hatással járó - önkormányzati erőfeszítéseket emelték ki. Így a menedzserlakások építésének ötletét, amelyet a város végül nem tudott megvalósítani, az angol nyelvü oktatási intézmények (óvoda, iskola) létrehozását. Ezek csak rövid ideig müködtek, később azonban megszüntek, amelynek fö oka, hogy nem volt rájuk, szolgáltatásaikra kelló számú igény (Szirmai-Baráth-Molnár-Szépvölgyi 2002). 


\section{A társadalmi és gazdasági hatások}

1) A kialakult gazdasági és politikai helyzetben a globalizáció, a transz-, illetve multinacionális tőke és a vállalatok megtelepedése alapvetően pozitív társadalmigazdasági hatásokat okozott. A megkérdezettek szerint modernebbé vált, megerősödött a lokális gazdasági szerkezet és a folyamatos versenyhelyzet miatt a talpon maradó hazai nagyvállalkozók is. A megjelenő külföldi cégek a munkanélküliséget aktív eszközzel, saját foglakoztatással enyhítették, miközben különbözỏ munkakultúrákat honosítottak meg, és ezzel sok esetben új termelési módszerek, hagyományok alapjait rakták le. Legtöbbször új technológiát hoztak és terjesztettek el, illetve folyamatos a technológia-fejlesztés, a technológiai transzfer, valamint korszerü termelés- és kereskedelemszervezési (logisztikai), szervezetfejlesztési és vállalatirányítási módszereket adtak át. Emellett folyamatosan kiemelkedỏ minőségi követelményeket támasztanak, illetve vezetnek be a beszállítók, az infrastruktúra és a kereskedelem, valamint a szolgáltatások tekintetében.

A gyártmány és a vállalat függvényében erősen differenciáltan, de esetenként mégis jelentős beszállítási lehetőségeket biztosítanak, és ezzel dinamizálják a lokális gazdaság bizonyos szegmenseit is. Ezeken a beszállító, illetve egyéb megbízásos jelleggel kapcsolódó kis- és középvállalkozásokon keresztül áttételesen, közvettet módon további jelentős munkaerőt alkalmaznak (másodlagos foglalkoztatás). Alkalmazottaiknak általában magasabb átlagos bérszínvonalat tudnak biztosítani, mellyel - szintén áttételesen - növekedett a térségi vásárlóerő is. Mindezeken túl az iparüzési adón keresztül, illetve egyéb formákban is (pl. dotáció, egyedi projektek) részt vesznek a lokális fejlesztésekben, sokszor infrastruktúrafejlesztésben is (pl. bevezető és elkerülö utak, zajvédelem, mủemlékvédelem, fásítás). Sok esetben támogatják a helyi kezdeményezéseket, a különbözỏ városi és térségi rendezvényeket, a civil szervezeteket, egyes intézményeket, sporteseményeket, illetve sport, müvészeti, tudományos stb. klubokat.

Részben e tényezők alapján is enyhült a korábban meglévő válság, az új vállalkozások, a beszállítói kapcsolatok megerősödtek, és a lokális gazdaság kiemelkedó fejlödésnek indult. Ezzel párhuzamosan azonban számos negatív társadalmigazdasági jelenség, veszély is felszínre került. A humán erőforrás fejlesztését közvetetten korlátozza például a többségében alacsonyan képzettek iránti permanens munkaerö-igény (föleg a külföldi cégek részéről), és az annak fenntartásában való érdekeltségük is. Sokszor figyelmen kívül hagyják az egyes korábbi lokális termelési hagyományokat, és a világpiaci érdekeket a lokális érdekek elé helyezik. Ezzel is összefüggésben kimutatható volt, hogy alapvetỏ érdekük a struktúrájában egyoldalú gazdasági szerkezet hosszú távú stabilizálása, a különböző gazdasági függőségi viszonyok, a versenyben elfoglalt egyenlötlen helyzetek fenntartása. A külföldi cégek egyben szükítik a hazai közép- és nagyvállalkozások müködési terét, terjeszkedési esélyeit, lehetőségeit is (fluktuációjuk esetén váltó-gazdálkodásban a hasonló profilura cserélődés miatt is). 
Tér és Társadalom, 17. 2003. 3. 29-57. p.

A helyben megtermelt profitot kivonják a lokális gazdaságból, és a globális tőkét érdektelenség jellemzi a helyi magasabb fokú oktatási, képzési és kutatás-fejlesztési tevékenységek, kooperációk terén is. A véleményekböl kiderült, hogy a jelzett negatív gazdasági hatásoknak egyéb kedvezőtlen társadalmi konzekvenciái is vannak: az utóbbi években például rendkívüli módon megnövekedett a munkavállalói bizonytalanság, és ennek fenntartásában a külföldi cégek érdekeltek. Területi és társadalmi-gazdasági elkülönülésük erôteljes, és részben a további közvetett hatásukra élezödnek az életszínvonalbeli különbségek is a lokális társadalmakban. Az érdekszférájukon kívül elhelyezkedő helyi kapcsolatokat sokszor tájékoztató jellegüvé degradálják. Egyes tevékenységükkel, vagy annak hiányával különböző társadalmi konfliktusokat gerjesztenek (pl. a környezetvédelem területén). Lokális fejlesztéseikre, támogatásaikra a bizonytalanság, kedvezményeik miatt pedig a lokális gazdálkodás visszafogása jellemző (adó-, vám- stb. kedvezmények igénylése, támogatások, szponzorálások megvonása stb.).

2) A térségi és városi népességre gyakorolt társadalmi következmények vizsgálatára nem volt módunk. Egy, az MTA Szociológiai Kutatóintézet által 2002-2003-ban megvalósított, a székesfehérvári és a tapolcai kistérségre reprezentatív - a lakosság környezettudatos magatartását feltáró - szociológiai kutatás szerint a megkérdezettek jelentős része - a mai értékelés szerint - negatívan élte meg az átalakulást, a külföldi cégek letelepedésének múltbeli hatásait. A megkérdezettek többsége szerint mindez elsősorban a szakmai elömenetel, a karrier, a szakmai önállóság és a társadalmi kapcsolatok tekintetében volt negatív hatású. A legkisebb negatív tendenciát az életkörülményekben és a jövedelmekben tapasztalták a megkérdezettek.

A pesszimista múltmegítélés ellenére úgy tünik, hogy a globális gazdaság konkrét térségi megnyilvánulásaival kapcsolatos elvárásokban, a jövőre vonatkozó elképzelésekben viszont már - mintegy óvatos várakozásként - pozitív tendencia is jelentkezett az életkörülmények, az életminöség és a jövedelmek tekintetében, és az élet más területein is csökkent az elörevetített negatív megítélés (Ferencz 2003).

3) Az átmenet keretében érvényesülő globális jelenségek a térségi társadalmat is érintették. A multinacionális vállalatok megjelenése, az ezzel is összefüggő gazdasági, társadalmi hatások egyrészt a térségi, illetve a városi társadalom szerkezetét, másrészt a térbeli elhelyezkedés viszonyait is átalakították. Hozzájárultak a piaci társadalmakra jellemző társadalmi, jövedelmi egyenlőtlenségek (pl. az állami és piaci szektor közti, a külföldi és magyar vállalatok közötti, a beosztás és a szakképzettség szerinti különbségek) kialakulásához.

Az államszocializmusra jellemző társadalmi szerkezet részleges átalakulását, a középosztállyá szerveződés térségi és városi nehézségeit, és a szegénység növekedését is lehet tapasztalni (Domaňsky 2001). Miközben a társadalmi és területi különbségek az ország hátrányosabb helyzetben lévö régióihoz és településeihez képest jóval kisebbek, a szegénység, az underclass jelenség kisebb mértékü. Ezt részben alátámasztja, hogy magas a fiatalok és munkaképes korúak aránya és beköltözése Fejér megyébe, a 60 év felettiek aránya kedvezően alacsony - 2\%-kal alacso- 
Tér és Társadalom, 17. 2003. 3. 29-57. p.

nyabb az országos átlagértéknél -, míg a munkanélküliek aránya mintegy 1\%-kal mutat kedvezỏbb képet az országosnál (a vidéki átlaghoz képest 2\%-kal). Magas, és folyamatosan növekszik - a vidéki átlag mintegy másfélszerese - az egy állandó lakosra jutó személyi jövedelemadó nagysága, és átlagon felüli a vállalkozások száma és dinamikája is (a vidéki megyeszékhelyeken 1000 lakosra 106 társas és egyéni vállalkozás jut, míg Székesfehérváron 122), ami a helyi lakosság kiemelkedöbb keresetén keresztül az életszinvonal emelkedését feltételezi. Székesfehérvár város önkormányzatának rendszeres pénzbeli szociális ellátásában és átmeneti segélyezésében (átlagosan évi 130 fỏ szorul rendszeres támogatásra - összehasonlításképpen a hasonló nagyságú Kecskeméten 1080 fö, Nyíregyházán 680 fő; de a jóval kisebb népességủ megyeszékhelyeken is magasabbak az értékek: Salgótarjánban 935, Szolnokon 410, Kaposváron 385, Békéscsabán 260 fö), illetve a jövedelempótlékban részesülők arányai is kedvezőbbek: mindezek jelezhetik leginkább a szegénység és az underclass jelenséghez köthető rétegek szükebb voltát.

A globalizáció általunk vizsgált folyamatai hozzájárultak a térségi területitársadalmi folyamatok eddigi trendjeinek átszervezéséhez. A differenciált gazdasági, jövedelmi, munkaerö-piaci lehetöségek az érintett társadalom, közte az elitcsoportok új lakóhelyi elhelyezkedését és a szegregáció új tendenciát is magukkal hozták (ezek részletes kutatására egy másik vizsgálat keretében van módunk). A szuburbanizáció felerösödését is tapasztalni, melynek - és az 1990-es évek közepétől megnövekedett bevándorlásnak - köszönhetöen a Fejér megyei falusi településállomány modernizálódásának, népessége stabilizálódásának, és a legtöbb helyen növekedésének is tanúi lehetünk (1990 óta 25 ezer fős vándorlási fogyás realizálódott a Közép-dunántúli régió városaiban, vele szemben 22 ezer fös gyarapodás figyelhetỏ meg a falvak javára). Mindennek pedig a legdinamikusabban fejlődő megyeszékhely környezete, a budapesti agglomeráció távolabbi vonzáskörzetei Bicske és Ercsi térsége -, valamint a velencei-tavi idegenforgalmi központok a célterületei (Baráth-Molnár-Szépvölgyi 2001).

A társadalmi-területi szerkezet átalakulása, a jövedelmi különbségek éleződése a térségi és városi társadalom, az elitcsoportok átalakuló életmódját és megújuló fogyasztási szokását is magával hozta. Miközben a nyilvánvaló különbségek miatt a globális és lokális aktorok közötti ellentmondások és a társadalmi - jövedelmi, érdekérvényesítési és életmódbeli - szakadékok növekedtek. A megkérdezett szereplök ezzel kapcsolatos értékelései azt mutatják, hogy a szakadékok az együttmüködés akadályait eredményezték, nehezítik a globális és lokális elitcsoportok közötti kapcsolatok alakulását.

4) A kutatás igazolta előzetes feltevéseinket, hogy a globalizációs folyamatok nem feltétlenül járnak együtt az érintett társadalmi-gazdasági szereplök térségi jelenlétével, illetve a térségi adottságok kizárólagos használatával. A globális és a helyi szereplők eltérỏ módon használják a lokális teret, a városi szolgáltatásokat, és a lakóhelyválasztási stratégiáik is eltérỏek ${ }^{3}$. Ez az integrációs folyamatokra is hatással van.

Elemzésünk szerint a megkérdezett magyar vezetők 60\%-a Székesfehérváron, 20\%-a pedig Budapesten él (20\% egyéb települések között oszlik meg). Az általuk 
Tér és Társadalom, 17. 2003. 3. 29-57. p.

44 Szirmai V.-Baráth G.-Molnár B.-Szépvölgyi Á.

megfogalmazott, magyar vezetőtársaikra vonatkozó vélemények is hasonló eredményeket tükröznek: eszerint a Székesfehérváron éló magyar vezetők aránya meghaladja a $60 \%$-ot, a Fejér megyében élőké pedig megközelítően 7\%. A fennmaradók többsége Budapesten, illetve Pest megyében lakik. A megkérdezettek közel $50 \%$-a véli úgy, hogy a külföldi vezetés egyáltalán nem telepedett le az országban. Nagyobb arányt képvisel a nem helyben (Székesfehérváron) történt letelepedés: a válaszadók kivétel nélkül Budapestet jelölték meg a külföldi vezetés lakhelyéül. Az okok között elsösorban a szolgáltatások minösége és az iskoláztatás lehetősége szerepel.

A multinacionális vállalatok térségi jelenlétére, társadalmỉ integrációjára a cégek helyi lakossággal, civil szervezetekkel kialakított kapcsolatai alapján is következtethetünk. A multinacionális vállalatok által kitöltött kérdöívek alapján megállapítható, hogy a válaszadó cégek közel $80 \%$-a áll kapcsolatban valamilyen módon a település lakosságával (1. ábra).

\section{1. ÁBRA}

A székesfehérvári multinacionális cégek kapcsolata a település lakosságával

(The Connections of the Multinational Companies in Székesfehérvár with the Population of the City)

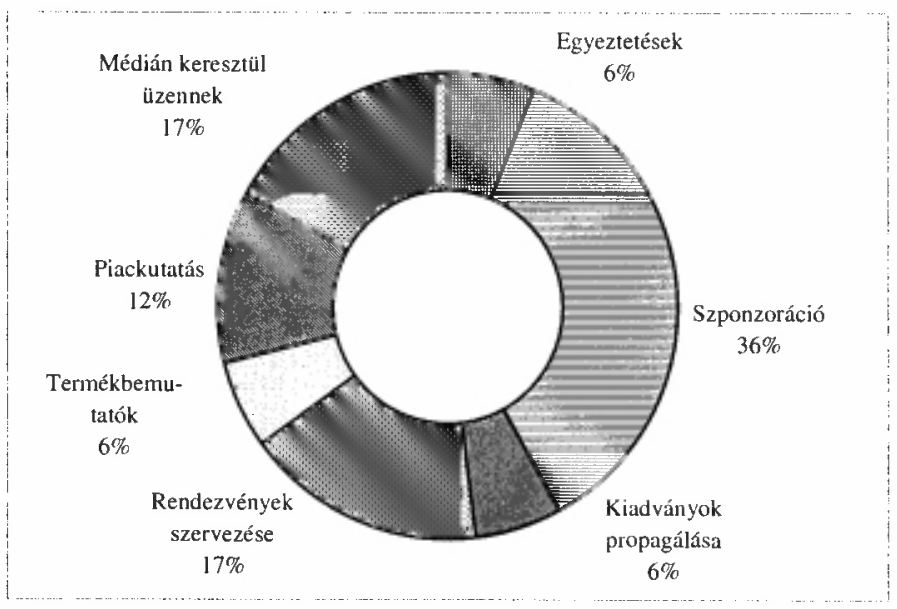

Forrás: Kérdőívek adatai.

A cégek Székesfehérvár lakosságával kialakított kapcsolatait legnagyobb mértékben a szponzorációval azonosítják (36\%). A megkeresett cégek között találunk olyat, mely többféle forrást is elkülönít szponzorációs célra, és a megkérdezettek szinte kivétel nélkül arra is ügyelnek, hogy többségében helyi kezdeményezéseket támogassanak. (Egyikük elmondta, hogy az anyavállalat és helyi leányvállalata is külön szponzorációs alapot müködtet, a pénzek elosztásáról pedig a hozzájuk beérkezett kérelmek, kezdeményezések alapján döntenek).

A támogatások, szponzorációs tevékenység mellett a lakossággal kialakított kapcsolatokat illetően legnagyobb arányt különböző rendezvények szervezése, illetve 
Szirmai Viktória - Baráth Gabriella - Molnár Balázs - Szépvölgyi Ákos:

Globalizáció és térségi fejlődés.

Tér és Társadalom, 17. 2003. 3. 29-57. p.

az azokon való részvétel képvisel (17\%). Ugyanekkora súllyal szerepel a város lakosságával a médián keresztül történö kapcsolattartás is, majd a piackutatás (12\%), az egyeztetések, a termékbemutatók és a különböző kiadványok propagálása következnek a sorban $(6 \%)$.

A városi civil elit képviselői a multinacionális vállalatok szponzorációs tevékenységét némileg másként értékelik. Véleményük szerint a multinacionális cégek bevételeikhez, méretükhöz, adottságaikhoz képest elenyészỏ összeget fordítanak a helyi kezdeményezések támogatására.

A multinacionális cégek a helyi közlekedési és kereskedelmi szolgáltatásokat, a biztonsági szolgálatot és a takarítást rendszeresen, az egészségügyi, kulturális szolgáltatásokat alkalmanként veszik igénybe. Vannak nagyon ritkán vagy egyáltalán nem igényelt szolgáltatások is (2.ábra).

\section{2. ÁBRA}

A székesfehérvári multinacionális cégek által igénybe vett szolgáltatások gyakorisága (The Frequency of the Services Used by the Multinational Companies in Székesfehérvár)

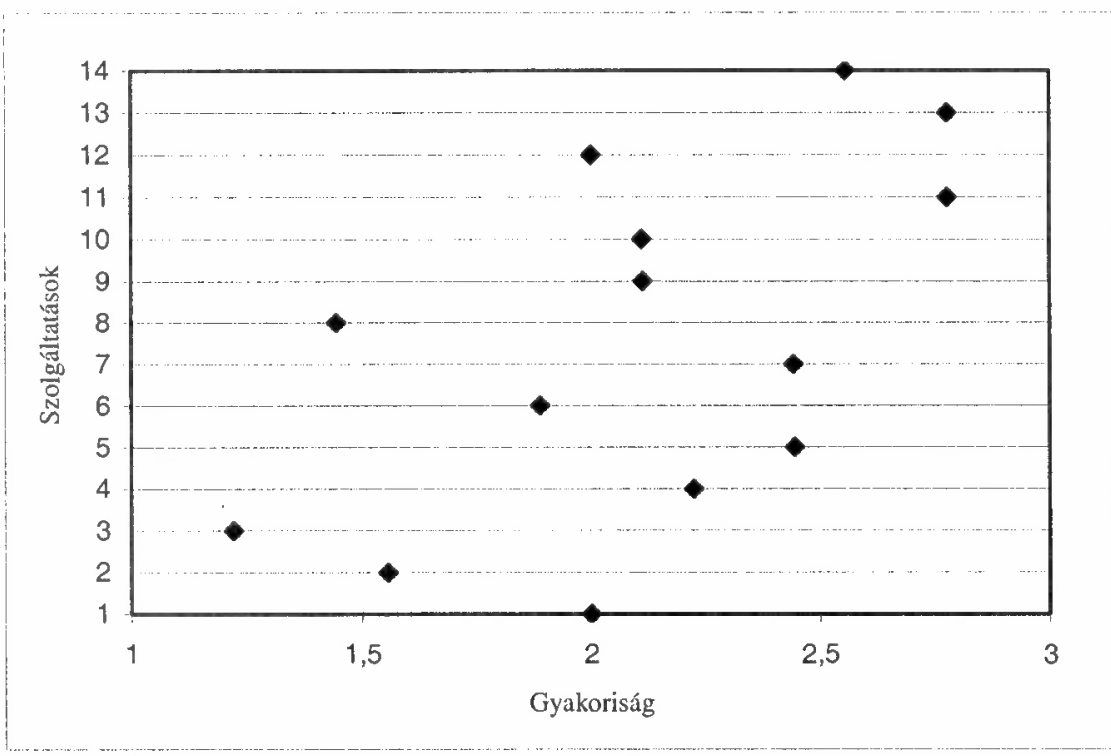

Jelmagyarázat:

X tengely: a szolgáltatások igénybevételének gyakorisága, ahol 1 - Rendszeresen, 2 - Alkalmanként, 3-Nincs.

Y tengely: szolgáltatások, ahol 1. Szállítmányozás-logisztika; 2. Telekommunikáció, hirdetés, reklám; 3. Helyi közlekedés, kereskedelem; 4. Pénzügyi/biztosítási szolgâltatások; 5. Raktározás, kölcsönzés; 6. Javítás; 7. Könyvelés-számvitel/adatfeldolgozás; 8. Biztonsági szolgálat, takarítás; 9. Egészségủgyi ellátás; 10. Kulturális ellátás; 11. Munkaeröfejlesztés; 12. Oktatás/szakképzés; 13. Szociális ellátás; 14. Különböző tanácsadások.

Forrás: Kérdöívek adatai. 
Tér és Társadalom, 17. 2003. 3. 29-57. p.

46 Szirmai V.-Baráth G.-Molnár B.-Szépvölgyi Á.

Megkérdeztük a cégeket a szolgáltatásokkal való elégedettségük mértékéről is (3. ábra).

\section{3. ÁBRA}

Az igénybe vett szolgáltatásokkal való elégedettség

(The Satisfaction with the Services)

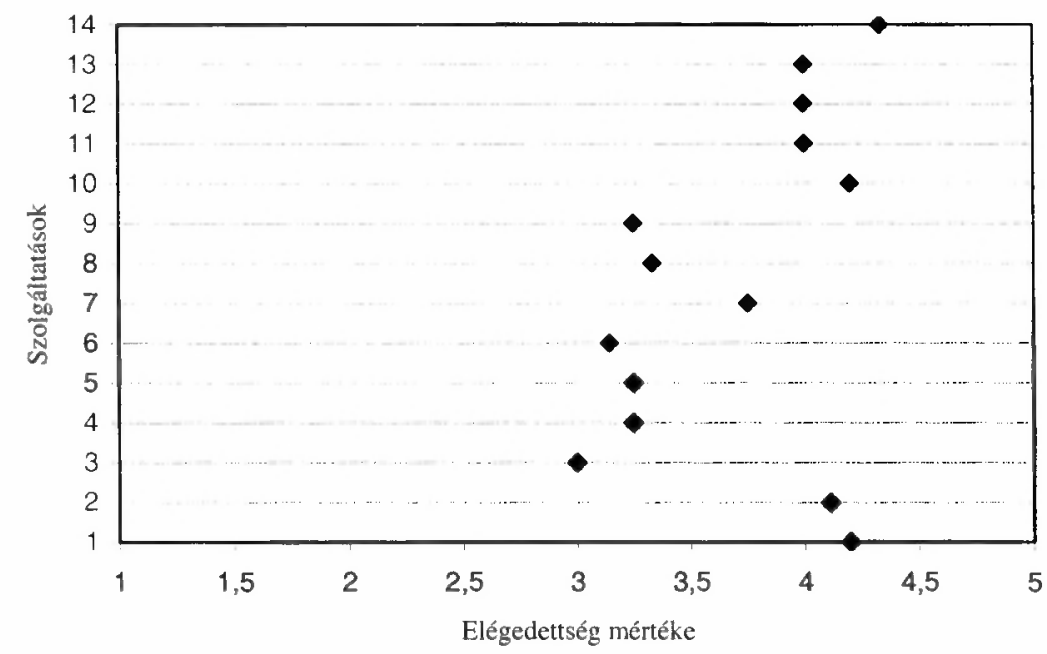

Jelmagyarázat:

$\mathrm{X}$ tengely: elégedettség mértéke, ahol $\mathrm{l}$ - legkevésbé elégedett, 5 - teljesen elégedett.

Y tengely: szolgáltatások, ahol 1. Szállítmányozás-logisztika; 2. Telekommunikáció, hirdetés, reklám;

3. Helyi közlekedés, kereskedelem; 4. Pénzügyi/biztosítási szolgáltatások; 5. Raktározás, kölesönzés;

6. Javítás; 7. Könyvelés-számvitel/adatfeldolgozás; 8. Biztonsági szolgálat, takarítás; 9. Egészségügyi

ellátás; 10. Kulturális ellátás; 11. Munkaeröfejlesztés; 12. Oktatás/szakképzés; 13. Szociális ellátás;

14. Kúlönböző tanácsadások.

Forrás: Kérdőívek adatai.

A cégek a közlekedés további fejlesztésének a szükségességét emelték ki elsősorban (elkerülő út építése, buszjáratok gyakorisága, úthálózat fejlesztése). Ezen túlmenően a lakásépítés, valamint a szakképzett munkaerő közvetítése, kölcsönzése szerepeltek a további fejlesztést igénylő szolgáltatások között.

A fentiekből kitúnik, hogy a cégek azokat a szolgáltatásokat veszik igénybe nagyobb mértékben, és azoknak a szolgáltatásoknak a fejlesztését tartják fontosnak, melyek müködésükhöz, költséghatékonyságukhoz szükségesek. A jelzett szolgáltatások igénybevétele természetesen nem jelenti a helyi társadalmi térbe történö integrációt, de annak bizonyos feltételeit adják. Ezt a feltételt jelentik a cégek magyar és külföldi menedzsmentje által rendszeresen igénybe vett helyi kulturális és szabadidős szolgáltatások is (4. ábra). 
Tér és Társadalom, 17. 2003. 3. 29-57. p.

TÉT XVII. évf. 2003 — 3

Globalizáció és térségi fejlödés

\section{4. ÁBRA}

A székesfehérvári multinacionális cégek által rendszeresen igénybe vett helyi kulturális és szabadidös szolgáltatások

(The Local Cultural and Spare Time Services Regularly Used by the Multinational Companies in Székesfehérvár)

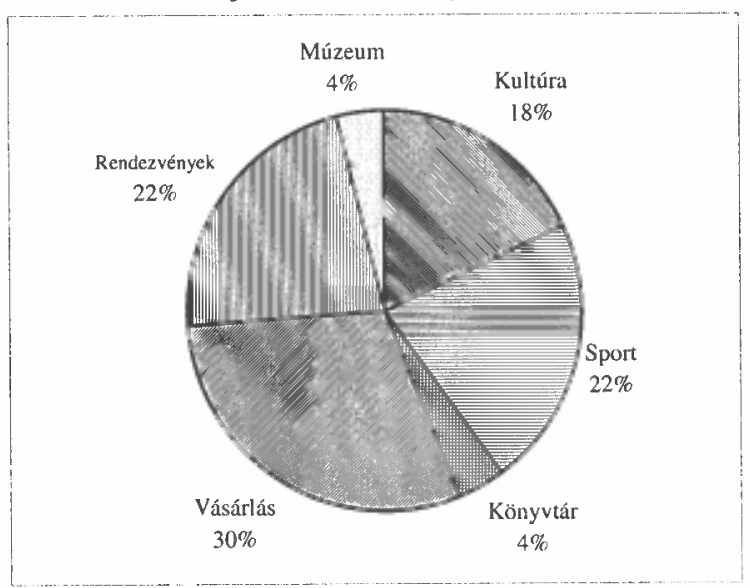

Forrás: Kérdőívek adatai.

A kérdőívet visszaküldök közel fele különbözö fejlesztési szükségleteket is megjelölt a kulturális és szabadidős szolgáltatások tekintetében. Ezek között a színház, a hangverseny és a különbözö sportolási lehetőségek szerepelnek (fitnessz, lovaglás, tenisz, fallabda). Vannak olyan szolgáltatások is, amelyeket többségében más településen vesznek igénybe a válaszadó cégek képviselői (5. ábra).

\section{5. ÁBRA}

A székesfehérvári multinacionális vállalatok képviselői által más településen igénybe vett szolgáltatások

(The Services Used by the Representatives of the Multinational Companies in Székesfehérvár in Other Settlements)

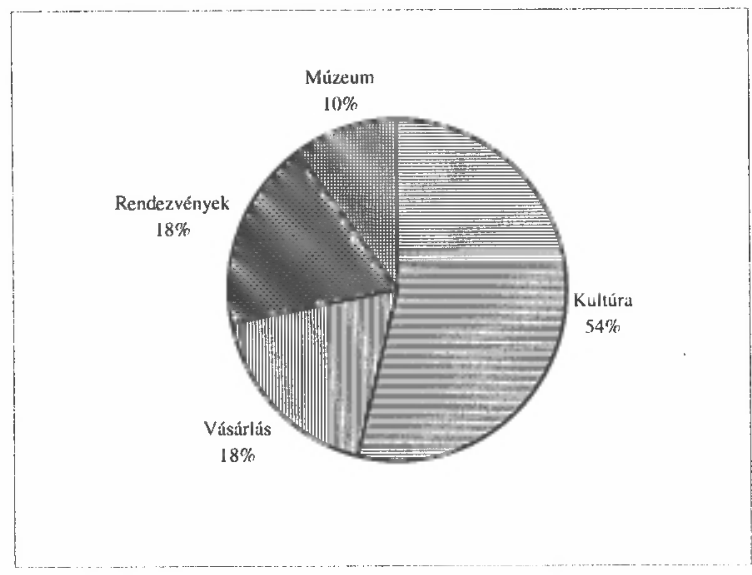

Forrás: Kérdőívek adatai. 
A legnagyobb arányt a kulturális szolgáltatások képviselik (54\%). Ezt követik a különbözö rendezvények és a vásárlási lehetőségek. A máshol (föként Budapesten) meglévő nagyobb kínálat, és az egyéb településen található lakóhely az oka a kialakult arányoknak.

Az interjúk szerint azokat a szolgáltatásokat, amelyek helyben megtalálhatók (éttermek, színház, mozi) és megfelelő színvonalúak, a multinacionális cégek magyar és külföldi menedzsmentje egyaránt szívesen igénybe veszi.

A multinacionális cégek és a városi elit közötti ellentmondásokra (kapcsolat és ismeret hiányokra) utalnak a városi elit által megfogalmazott vonatkozó nézetek: „Nagyon kevés szolgáltatást vesznek igénybe, aminek sokszor az az oka, hogy nincs is igazán igénybe vehetö szolgáltatás. Érdekes, hogy csak körülbelül fél éve van a városban színvonalas hotel, közben a multik már tíz éve letelepedtek. Nincsenek megfelelö éttermek, vendéglök. Egyéb szolgáltatásokat meg végképp nem vesznek igénybe, mert otthonról hozzák öket".

A gazdasági-, területfejlesztési szakértők véleménye szerint elsősorban azokat a szolgáltatásokat veszik igénybe, amelyek vállalatuk múködéséhez szükségesek.

A tények szerint tehát a globális aktorok a helyi adottságoknál szélesebb társadalmi és lakóhelyi teret teremtenek maguknak. Ezek a tényezők a kutatott típusú integráció ellen szólnak. A különbözö szintü térhasználat ma még a globális és lokális aktorok közötti térbeli, lakóhelyi konfliktusok forrása, melynek okai éppen a globális és a lokális tér átszervezödésével kapcsolatos folyamatok és az eltérő értelmezések, miközben a globalizáció szükségszerü folyamataival állunk szemben. A helyi elit helyzetének differenciáltsága szerint tudja csak elfogadni a külföldi vállalatok vezetőinek életformáit, a szegregáció folyamatait, azt, hogy saját lakóhelyi tereket hoznak létre, s ezek nem feltétlenül esnek egybe a helyi elitcsoportok lakóhelyi tereivel. Legtöbbször a városi elit életformái sem esnek egybe a külföldi cégek vezetöinek mobil, helyi és globális terekre kiterjedő életformáival.

5) A térségi, helyi politikai és hatalmi struktúra függỏ helyzetbe került az átmenet keretében, részben az állami centralizációs törekvések, a központi és a helyi pártpolitikai összetétel eltérései, részben pedig a globális szereplőknek való kiszolgáltatottságok szerint.

$\mathrm{Az}$ átmenet elején kialakult nehéz helyzetben a helyi hatalom képviselöinek nem volt módjuk, sem erejü a védekezés kidolgozására: az átmenet levezénylése volt a fö feladat. Ebben azonban szinte teljes társadalmi és politikai konszenzus jött létre, kiváltképp a válság idején. Ezt az is mutatja, hogy csak nagyon kevesen próbálták meg a globális függéseket és az azokból adódó valóságos társadalmi problémákat politikai célokra is felhasználni. A politikai érdekérvényesítés mechanizmusaiból általában kimaradt ez a szempont. A globalizáció ellentmondásos hatást gyakorolt a térségi és városi politikai elit lehetöségeire. A térségi és városi politika befolyását növelték egyrészt a globális szereplök letelepedését pártoló és megalapozó fejlesztési koncepciók és programok, a szuikséges intézmények kialakítása is. Befolyásukat növelték a munkahelyteremtő törekvések is, a foglalkoztatási gondok enyhítése és enyhülése, az ideérkező befektetések és külföldi cégek, de legföképpen az elért 
Tér és Társadalom, 17. 2003. 3. 29-57. p.

gazdasági sikerek, a térségi átmenet megvalósítása. A térségi és városi politika befolyását növelte másrészt az is, hogy a multinacionális cégek menedzsmentje nem törekedett térségi politikai részvételre, miközben a legfontosabb szociális feszültséget, a munkanélküliség veszélyeit jelentős mértékben enyhítették.

A térségi politikai befolyást azonban csökkentette a multinacionális cégek telephelyválasztási stratégiáinak való kiszolgáltatottság. Ezt a befolyást most különösképpen veszélyeztetik a térség jövöjével, a külföldi tökebefektetésekre alapozott modell fenntarthatóságával kapcsolatos kételyek, a meglévő modell müködését veszélyeztető társadalmi és gazdasági problémák, különösképpen az egyes külföldi vállalatok kivonulása.

\section{A jövö lehetöségei: a térségi válaszok}

\section{Lehetett-e másképp fejlödni?}

A ma visszaemlékezö megkérdezettek nézetei között nem találtunk releváns különbséget, a globális és lokális ,találkozást” a helyi elitcsoportok támogatták. A korabeli ideológiáknak és koncepcióknak megfelelöen a térségben is csak mérsékelten figyeltek a gazdasági csatlakozás, illetve a globális gazdasághoz történő integráció várható negatív társadalmi következményeire. A várható társadalmi konfliktusokról és nehézségekröl alig esett szó. A kilábalás lehetöségében akkor egyértelmü társadalmi konszenzus volt, azt a kényszerhelyzetben lévő lakosság is - a válsághelyzet hatására hallgatólagosan - elfogadta, tudomásul vette, támogatta.

A vizsgálat keretében megszólaló társadalmi-gazdasági szereplők, a különböző elitcsoportokat képviselök a kialakult térség- és városfejlödési irányt ma is elfogadják, noha társadalmi és szervezeti érdekeltségeik, a hatalomhoz - pl. a pártokhoz, az önkormányzatokhoz -, illetve a civil társadalomhoz való közelségük alapján eltéróen értékelik. A mélyinterjúkból az is egyértelmủen látszik, hogy az elitcsoportok nem csupán elfogadták a globalizáció térségi jelentkezését és összes hatásait, hanem nem is láttak, nem találtak más utat, $\mathrm{s}$ az akkori szituáció sem kínált mást. A globális gazdaságba való integrációt részben lehetőségként, részben kényszerként élték, élik meg. A meghatározottságok alapján elfogadják a függỏ helyzetet, de a belső motivációk és értékrendek alapján egyben el is utasítják azt.

A megkérdezett csoportok képviselöi alapvetően a társadalmi helyzetük, érdekeltségeik szerint minősítik a lezajlott folyamatokat. A gazdasághoz kötódő aktorok sokkal inkább elfogadják a globalizációt - a pozitív gazdasági következményekre helyezve a hangsúlyt -, mint a többi elitcsoport képviselöi. Az önkormányzati szféra képviselöi látják a társadalmi problémákat, de föként azok nem túl éles voltát és kezelhetőségüket emelik ki. A civil, a kulturális, a tudományos szféra sokkal keményebben bírál, a gazdasági előnyök mellett sorra veszik és hangsúlyozzák a társadalmi következményeket, a negatív tényezőket is.

Az interjúkból kitủnt, hogy a térségi elit értékeli és elismeri az eddigi fejlödés eredményeit, pártállástól és szervezeti kapcsolataiktól függetlenül. Tisztában van- 
Tér és Társadalom, 17. 2003. 3. 29-57. p.

nak a város és a térség 1980-as években kiéleződött komplex válságával és az akkori nehézségekkel, valamint azzal is, hogy a kilábalás nem sikerült volna a külföldi tőkebefektetések nélkül. De úgy gondolják, hogy a székesfehérvári siker fontos feltétele volt az érintett elitcsoportok részvétele is. Általános elit vélemény azonban, hogy a siker nem csak az elitcsoportok tevékenységének az eredménye. A térségi, városi társadalom történetileg is kondicionált szakmai kulturáltsága, a lokális gazdasági funkciókból adódó szakértelem, a földrajzi helyzet, a kedvező infrastrukturális adottságok, a meglévő vállalati kultúrák és intézmények egyaránt hozzájárultak az új típusú fejlödéshez. Vagyis a multinacionális vállalatok telephely-választási stratégiáinak ezek voltak a konkrét feltételei.

A megkérdezettek többsége látja a kedvezőtlen következményeket, a társadalmigazdasági problémákat is. Ezek részben a piaci társadalom jellegzetességeibỏl, a globalizációból és az átállásból adódnak. Sokan megfogalmazták, hogy nem mindenkinek oldotta meg a helyzetét a piacgazdaság, a globálizálódó gazdaság, a multinacionális cégek megjelenése, bár ezek nagyon sok - a privatizáció során - utcára került, munkanélkülivé vált embert felszívtak, rengeteg embernek adtak ismét munkát. Ennek ellenére a munkanélküliség problémái kismértékben ugyan, de megmaradtak - így pl. az erejüknek még teljében lévö, de kényszer-nyugdỉjaztatással nyugdijba kerültek gondjai is -, ami kiegészültt a munkalehetőségek bizonytalanságával, a gyakori fluktuációval (Szántó-Tóth 2002).

$\mathrm{Az}$ átalakuló térségi gazdaság, az új nagyvállalatok a környékrỏl, más megyékböl is vonzották a munkaeröt. Ez részben jó volt a városnak, hiszen megoldotta az itteni cégek munkaerőigényeit, a városba pedig új lakókat - sokszor csak nappali népességet, új munkaerőt - is vonzott. Bár ennek konfliktusai is voltak, hiszen a korábbi szociális lakásépítkezések leállásával növekedtek a térségi lakásproblémák, a lakásigények újrastrukturálódtak. A munkásszállások megszủnése is lakásgondokat okozott. Ezek megoldására az akkori gazdasági helyzetben az önkormányzat gondolni sem tudott, a lakásszektor immár piaci alapú átalakítása, átalakulása új keletủ folyamat. Ma már egyre többet foglalkoznak ezzel Székesfehérváron is, akárcsak minden városban, jelentỏsebb településen, csakhogy, azóta további új igények is felmerültek. A fiatal szakértelmiségiek, de a külföldi cégek menedzserei is minöségi lakás-, új lakópark fejlesztéseket, vagy színvonalas bérleményeket várnak el föleg azokban a városokban, ahol a globális gazdaság képviselöi kézzel foghatóan jelen vannak. Ezek az igények azonban a mainál jóval differenciáltabb lakáspolitikát, lakásmodellt és új lakáspiaci kínálatot igényelnek (Hegedüs-Tosics 1998; Egedy 2001).

A humán eröforrás szerkezetét tekintve a városban és a térségben egyszerre van sajátos munkaerőhiány és munkaerő-felesleg is. A jövőben várható intenzív gazdaságfejlődés a maitól eltérö, egyben sokkal képzettebb munkaerö struktúrát feltételez. A térség- és városfejlesztési elképzeléseknek célszerủ ezekre a szempontokra építenie, amely a legújabb munkaerö-piaci felmérési törekvésekben és kutatásokban helyet is kapott. 
Tér és Társadalom, 17. 2003. 3. 29-57. p.

A globális gazdaság az átmenet keretében kibontakozó kedvezőtlen jelenségek és az örökölt történeti problémák közül sokat megoldott, a város új fejlődési pályára állt egy másik társadalmi berendezkedés törvényei szerint. Az új pálya sokaknak javított a helyzetén, de nem kevés azok száma sem, akik rosszabb körülmények közé kerültek. A szakértelmiségiek közül is sokan kerültek a korábbi státuszukhoz képest alacsonyabb beosztásba, végeznek kevésbé kvalifikált munkát külföldi cégeknél.

Székesfehérvár a térségi modernizációban is kiemelt gazdasági és társadalmi szerepet játszik, mely szerep a korábbi történeti folyamatoknak - ha úgy tetszik, hagyományoknak - megfelelöen jött létre. Ez a helyzet különösképpen nyilvánvaló, ha a fejlődésben lemaradt egyéb térségekkel hasonlítjuk össze a várost és környékét. A „székesfehérvári modell” a követendő társadalmi-gazdasági és területi fejlődés modelljeként, a versenyképesség, az európai térség- és városhálózatba történő sikeres csatlakozás reális útjaként fogalmazódik meg. Legalábbis eddig ez így szerepelt (Molnár 2003). Többek véleménye azonban, hogy ma már új utakat és új modelleket kell keresni, alapvetően a gazdaság árnyoldalai miatt. De azért is, mert a centrum jobban fejlődött, mint a periféria, illetve átalakult a centrum és a periféria, valamint azok kapcsolata is.

Társadalmi és terưleti-társadalmi szigetek, a jobb jövő lehetőségei - nem csak reményei - jöttek létre a vizsgált térségen belül (is), a társadalmi egyenlötlenségek erősödtek, nyilvánvalóbbá váltak. Ezek a szigetek túlmutatnak a multinacionális vállalatok és a környező gazdaság szigetszerüségének problematikáján. Miközben kétségkívưl különösképpen erős volt a fregmentáció a multinacionális vállalatok és az azok vonzásán kívül rekedtek között. De éleződtek a belső egyenlötlenségek a multinacionális vállalatok alkalmazottai esetében is (Bódis 2002). Különböző szakmai képzettségü, illetve magasabb státuszú csoportok között is különbségek jöttek létre. A titok hangulata és föként követelménye vette körül a multinacionális vállalatok belső viszonyait, miközben a titok ellenére mindenki számára nyilvánvalóvá váltak az egyenlötlenségek. Ezek miatt, de a veszélytudat miatt is csökkent a társadalmi kohézió.

A problémákat növelte, hogy leépült az állami, a hatósági, a szociális és a kulturális szféra, valamint a városi társadalmi, lakóhelyi élet fejlesztési, fejlődési igényei is háttérbe szorultak. A gazdaság akkori átalakulása miatt erre sem figyelem, sem forrás nem, vagy alig jutott.

Miközben a multinacionális vállalatok, noha saját érdekeik és gazdasági szempontjaik alapján, de azért szociális intézkedéseket is hoztak. Ezek a nem formalizált intézkedések azonban csak a jelzett cégek dolgozóira és azok családjaira vannak hatással, a többiek, a többi városlakó kimarad ebből a kialakulatlan - a multinacionális cégek helyi képviselői számára is sokszor idegen, szabályok nélküli, egyéni kapcsolatokban formálódó, sokszor a jóérzésükre, szolidaritás-tudatukra építö rendszerből. Ez szintén kettős hatással volt a helyi társadalmi kohézióra: a szociális problémák kezelése révén növelte, a kimaradtak révén pedig csökkentette a térségi összetartozást és annak tudatát is. 
Tér és Társadalom, 17. 2003. 3. 29-57. p.

52 Szirmai V.-Baráth G.-Molnár B.-Szépvölgyi Á.

\section{A ,globális" és ,lokális” kapcsolatok}

Az interjúk tanúsága szerint inkább csak méregetik egymást a globális és lokális aktorok, még a másiktól várják leginkább a kezdő lépést, bár már meghívták egymást „,vacsorára”, ahogy a LaFontaine mesében a róka tette a gólyával. De mindkét fél olyan edényben tálalt, ami még csak a meghívó félnek volt jó, a másik fél nem, vagy nehézségek árán jutott hozzá a feltálalt ételhez. Paralel módon a hiányzó integrációért még többnyire mindenki a másikat hibáztatja. Mindkét fél számos példát hoz a legkülönbözőbb típusú kezdeményezésre, és arra, hogy a másik fél volt az, aki nem fogadta, nem reagált a lehetöségekre. Mindez azért is van, mert még túl közeli az idő, amikor az átalakulás elkezdődött. Még túl közel vannak a globalizációból adódó fájdalmak, az okozott társadalmi átállás nehézségei, a kialakult hátrányok és a vélt vagy valós igazságtalanságok. Sokan vannak a vesztesek között, de a nyertesek sem igazán nyertesek, föként hosszú távon nem azok. Egy ilyen mértékü társadalmi átalakulásban végül is mindenki nyertes és vesztes is egy kicsit, bár ez társadalmi rétegenként igencsak eltérō.

A külföldi partnerek is kiszolgáltatottak a világgazdaságnak, a multinacionális vállalat központjának, vagy a profitnak. S erre sokszor nem is gondolunk. Annak ellenére, hogy számos külföldi cégnek - az ország viszonylagos nyitottságának köszönhetően - már az 1980-as években, illetve korábban is voltak magyarországi, térségi kapcsolatai. A külföldi menedzserek közül egy évtizede sokan azt sem igazán tudták milyen országba, föként milyen térségbe vagy városba érkeznek. Szintén kérdéses volt, hogyan tudják megvalósítani eredeti terveiket, megállják-e a helyüket, meddig maradnak itt, illetve érdemes-e egyáltalán berendezkedni?

Az interjúkból is egyértelmủen kiderült, hogy mind a multinacionális cégek, mind a térségi és városi politikákat képviselök fontosnak tartják a jó együttmüködést. Bár egyelöre a hosszú távra berendezkedő cégeknek van, illetve lenne erre leginkább szükségük. A globális gazdaság hosszú távú érdekviszonyai ugyanis ezt feltételezik, hiszen ebben az együttmüködésben alakulhatnak ki és fejlödhetnek tovább a globális és lokális gazdaság és társadalom ma még zömében hiányzó partnerkapcsolatai.

A tények szerint az együttmüködés azért sok szempontból létezik már ma is. A gazdaságban kiváltképp: a globális és térségi gazdaság aktorai között különböző hullámzással és különbözỏ valószínüséggel - leginkább az aktív piacbefolyásolás, a nyereségesség és a perspektivikus vállalati magatartás pozitív függvényében és tiszta tulajdonviszonyok mellett - müködik a kooperáció (Csabina-Leveleki 2000). A globális gazdaság, érdekpolitika és a lokális politika is törekszik az együttmúködésre, bár úgy tủnik, mintha ez a válságperiódusban erősebb lett volna. Az IBM kivonulását követő helyzetben szintén újra erösödni látszik a kölcsönős együttmüködés, a kommunikáció iránti igény.

Az elemzések szerint a multinacionális cégek dolgozói is ",használják” a várost, a térséget. A cégek szponzoráló tevékenységeire több példát is láttunk. Ezek intézményesítése elörelépést jelenthetne. Mindenki úgy gondolja azonban, hogy a lényeg az, hogy a vállalatok befizetett iparủzési adója és egyéb központi támogatásai a 
városban maradnak (ez akkor is igaz, ha a külföldi töke vonzása érdekében átmenetileg jelentős adókedvezmények léteznek egyes térségekben, mivel a legtöbb cég esetében letelepedési döntésüknél a helyi adóknak, városi kedvezményeknek elenyésző szerepe van).

Az interjúkból az is kiderült, hogy a globális szereplök helyi képviselöi, köztük a külföldi alkalmazottak figyelnek a térségben, a városban zajló eseményekre, hogy a politikai és gazdasági stabilitás különösen fontos számukra. Alapvetöen jól érzik magukat Székesfehérváron. S ezt fontos tényezöként jelölik meg - noha ók is, mi is tudjuk -, hogy ez sem a legdöntőbb tényezője az idejövetelüknek, sem a maradásuknak, a hosszú távú társadalmi-gazdasági integráció szempontjából ez mégis kiemelten jelentós lehet.

\section{A fejlödés további lehetöségei}

A vizsgálat keretében megkérdezettek a jövőbeli fejlődés lehetőségeit a megkezdett térség- és gazdaságfejlődési modell továbbvitelében, de annak továbbfejlesztett változatában látják. Nagyon sok javaslat hangzott el. A különböző helyzetben lévő társadalmi szereplök ugyan helyzetük eltérései szerint más és más hangsúlyokat tettek, a javasatok fö tendenciájában nincs különbség.

A továbblépés lehetőségét szinte mindenki térségi, helyi szinten, és nem felülröl képzeli el, vagy kívülről jött megoldást remél. Ez az állami támogatásokkal kapcsolatban is igaz. Nincs vita abban sem, hogy ez csak együttmüködéssel, az érintett társadalom - a megszólalók szerint fő́ként a különböző szakmai csoportok - részvételével oldható meg. Az érintett aktorok véleményéböl az is kiderült, hogy ezzel kapcsolatban még számos probléma merül fel: intézményi és politikai korlátok, látszatviták, és az érdekek harmonizációját biztosítani nem képes tevékenységi módok, a konfliktuskezelés még mindig hiányzó eszközei, valamint a hiányzó, de az elörelépéshez nélkülözhetetlen kölcsönös információáramlás és kommunikáció.

A jövőkép, a hosszú távú stratégia megalkotása, a határozott önkormányzati beavatkozás, a koncepcionálisan végiggondolt és feltételekkel is felruházott irányítás a legfontosabb javaslatok közé tartoznak. Ezeket föként az önkormányzatokhoz közel álló erök és a civil csoportok képviselöi említették. A gazdaságot reprezentáló szereplök továbbra is a befektetést ösztönző politika jelentőségét, a befektetök támogatását, a térség újra vonzóvá tételét tartják megoldásnak. Az együttmúködés a köz- és privát szféra között, a megyei és városi önkormányzat, a vállalatok, a külföldi és hazai gazdaság képviselöinek közös tevékenysége, valamint ezek nyilvános értékelése szintén a javaslatok között van.

A széles társadalommal való kommunikáció kiterjesztésének, de leginkább kulturált formáinak megteremtése azonban többnyire hiányzik a megfogalmazott javaslatok közül. Ez azért baj, mert véleményünk szerint ez adhatná mind a megyei, mind pedig a városi önkormányzat legnagyobb támaszát, új erejét, valamint a térségi, a lokális érdekérvényesítés legfontosabb feltételét, a globális folyamatok egyoldalú érvényesülésének lokális társadalmi ellenpontját. 
Tér és Társadalom, 17. 2003. 3. 29-57. p.

További kutatásokat igényel, hogy miért hiányzott a széles társadalmi kommunikáció és részvétel a javaslatok közül. Feltevésünk az, hogy az elitcsoportok a gazdasági folyamatok fejlesztését, a térségi gazdaság fellendítését még mindig többnyire szakmai kérdésként értelmezik, a megoldást kizárólag a gazdasági erőterekben helyezik el, és nem gondolnak a társadalmi összefüggésekre. Miközben a nemzetközi és a hazai szakirodalomban is terjed a gazdasági és társadalmi szempontokra kölcsönösen építö térség- és városfejlesztés ma még inkább koncepciója, mint gyakorlata (Szirmai-A. Gergely-Baráth-Molnár-Szépvölgyi 2002).

A megfogalmazott jövöképben sok minden benne van: a korábbi államszocialista illúziókkal való leszámolás, de a globalizáció ma már sokkal kritikusabb és egyben pragmatikusabb értékelése, a multinacionális vállalatoktól való, még mindig létezó félelem és az adaptáció esélye is. Egyre többen fogadják el, hogy így mủködik a mai világ, problémákkal és nehézségekkel, de azt is érzik, hogy ezekre fel kell készülni. S ez azért fontos, mert korábban a térségi irányítás figyelméböl kimaradtak a globális társadalmi problémák, a külföldi tökebevonásra épitő átmenet kedvezőtlen következményeinek kivédésére, a pozitív hatások védelmére irányuló elképzelések és programok. Az ezzel kapcsolatos kommunikáció nemcsak az 1990-es évek elején hiányzott, hanem még ma is kevés szó esik széles nyilvánosság elött a problémákról, azok enyhítésének és kezelésének koncepcionális értelmezéséröl.

Talán ezért is van, hogy a ,hogyan” még kevésbé világos. Bár a megkérdezettek többnyire optimisták, $\mathrm{s}$ ez részben azért is jó, mert az optimizmus mozgósító erő. De csak akkor, ha az optimista szemlélet mellé valóságos elemzések is párosulnak. Az ilyen elemzések többféle olyan szcenáriót vázolhatnak fel, amelyek a lehetséges esélyeket latolgatják, és azok gazdasági, társadalmi, politikai és környezeti feltételeit és következményeit, valamint a lehetséges területi-társadalmi konfliktusait is számba veszik. A kapcsolódó és ellentmondó érdekek hálózatát, a feloldás, a harmonizáció eszközeit és azok társadalmi szereplőit is végiggondolják. Az interjúinkban megfogalmazott forgatókönyvekből azonban hiányoznak a negatív szcenáriók, a védelem eszközei.

A korábbinál relevánsabb jövőkép kialakítását nehezítik a helyi, térségi, regionális, de tegyük hozzá a nemzeti szintủ hosszú távú tervezés nehézségei is. A globális függések, a külső meghatározottságok alapjån nem könnyủ helyi, regionális szinten - kiváltképp rövid távon -prioritásokat kijelölni. A hosszú távú tervezést talán segíteni fogja az Európai Unióhoz történő csatlakozás, és az ott elfogadott, föként a fenntarthatósággal kapcsolatos értékek, melyek a gazdasági, társadalmi és környezeti érdekek összekapcsolására törekszenek. A többféle érdek harmóniáját biztosítani törekvő nézetek célja a globális gazdaság kedvezőtlen társadalmi hatásainak korlátozása, enyhítése. 
Tér és Társadalom, 17. 2003. 3. 29-57. p.

\section{Összegzés helyett}

A külföldi tőkebefektetésre alapozott térség- és városgazdasági fejlődési modell eredményekkel, de meghatározott társadalmi problémákkal és feszültségekkel is együtt járt. Ezek az adott gazdaságfejlődési modell olyan lényeges jellemzőiként írhatók le, amelyek a globális, egyben gazdasági érdekek túlsúlyából, a lokális, egyben a társadalmi érdekek szük keresztmetszetủ érvényesüléséből jönnek létre.

A hosszú távon fenntartható térségi gazdasági és társadalmi fejlődéshez, a térségi versenyképességhez továbbra is szuikségesek a globális hatások, így a transz-, illetve multinacionális vállalatok jelenléte is. A mainál azonban kisebb mértékü függésekben, erőteljesebb térségi, városi irányitással, és az érintett és érdekelt aktorok kifinomult együttmüködésével.

Fontos lenne az integráció erősítése is, a globális és a lokális gazdaság és társadalom közötti kapcsolatok javítása. Ezek a kapcsolatok részben történeti okok, részben a mai folyamatok és érdekek miatt még esetlegesek, nem beszélhetünk a két (egyben differenciált) szféra erős integrációjáról. Ma még valóban jellemzőek a függések. Miközben érzékelhetök pozitív tendenciák, a globális és a lokális folyamatokat, érdekeket képviselő társadalmi, gazdasági, politikai aktorok közötti integrációk, a gazdasági és társadalmi jellegü kölcsönös kapcsolatok szervezödései is. Az elitcsoportok fontos szerepet játszottak a globalizációs folyamatok megvalósulásában, miközben nem fordítottak figyelmet sem a globalizációs problémák kivédésére, sem pedig a széles társadalmi kommunikációra. A kedvező változáshoz, a „hogyan tovább?" kérdésre adott válaszokhoz új térségi, városi társadalmi megegyezésre, széles körủ társadalmi konszenzusra, a civil participációra alapozott új jövőképek kialakítására van szükség.

\section{Jegyzetek}

${ }^{1}$ Az empirikus kutatások keretében két módszert alkalmaztunk. Egyrészt önkitöltỏs kérdőívet küldtünk a Székesfehérváron és Fejér megyében müködö multinacionális vállalatoknak. Ebben a vállalati kapcsolatrendszereket és a telephelyválasztási tényezőket vizsgáltuk. Ezzel párhuzamosan az érintett településeken (Székesfehérvár, Dunaújváros, Mór) strukturált mélyinterjúkat készítettünk a multinacionális vállalatok társadalmi-gazdasági kapcsolatrendszereinek, telephelyválasztásuk meghatározó tényezöinek feltárása érdekében. A mélyinterjúk segítségével megkeresett szereplök kiválasztásánál törekedtủnk arra, hogy minden érintett szereplővel készüljenek interjúk, így megkerestük a multinacionális vállalatok képviselöit, a beszállítóként tevékenykedö helyi kis- és középvállalkozásokat, valamint a gazdaság- és területfejlesztésben érintett szakembereket. Ezen túlmenően interjúkat készítettủnk az érintett önkormányzatok szakembereivel, a civil társadalmi szervezetek, a felsőoktatási intézmények és a városi társadalmi elit képviselöivel. A vizsgálat során 44 kérdőívet küldtünk ki és 39 strukturált mélyinterjút készítettünk. A kérdőíves vizsgálat eredményeként a kérdőívek $20 \%$-a érkezett vissza. A kérdőívet visszaküldő vállalatok kivétel nélkül székesfehérvári illetőségủek voltak, igy esetükben a visszaküldési arány közel $30 \%$. A mélyinterjúk valamivel több mint $40 \%$-a a gazdasági szereplỏkkel, így a multinacionális vállalatok és a helyi kis- és középvállalkozások képviselöivel, 15\%-a az érintett önkormányzatok szakembereivel, 20\%-a a gazdaság- és területfejlesztésben érintett szakemberekkel, és közel $25 \%$-a a civil társadalmi szervezetek, oktatási intézmények és a városi elit képviselöivel készuult.

${ }^{2}$ Egy korábbi nemzetközi összehasonlító és egy hazai vizsgálat keretében Tatabánya térségében is tapasztaltuk a szigetszerủséggel kapcsolatos problémákat, miközben egy új folyamatot, vagyis a multinacionális cégek - a város gazdasági életében betöltött szerepvállalásuknak megfelelỏ - társadalmi 
Tér és Társadalom, 17. 2003. 3. 29-57. p.

56 Szirmai V.-Baráth G.-Molnár B.-Szépvölgyi Á.

integrációs törekvéseit, szponzorálási céljait, a városfejlödés támogatását is érzékeltük (SzirmaiBaráth-Molnár-Szépvölgyi 2001a; 2001b).

3

A globális és lokális gazdasági szereplők lakóhely-választási stratégiái feltárásához és értékeléséhez módszertanilag egy áthidaló megoldást alkalmaztunk. Külön kezeltủk és elemeztủk a multinacionális cégeknél dolgozó megkérdezett magyar menedzserek lakóhelyválasztását és az általuk megfogalmazott magyar és külföldi vezetötársaik lakóhelyére vonatkozó vélekedéseket.

\section{Irodalom}

Artner A. (2003) Globalizáció-kritika a világban. MTA VKI, Budapest.

Baráth G.-Molnár B.-Szépvölgyi Á. (2001) Területi egyenlőtlenségek a Közép-Dunántúlon. - Tér és Társadalom. 1. 111-129. o.

Barta Gy. (2002) A magyar ipar terïleti folyamatai 1945-2000. Dialog-Campus Kiadó, Budapest-Pécs.

Bauman, Z. (1998) Globalization: the human consequences. Polity Press, London.

Bódis L. (2002) A multinacionális tömeggyártó üzemek és az állami munkaközvetítés. - Szociológiai Szemle. 1. 21-45. o.

Csabina Z.-Leveleki M. (2000) A vállalatok kooperatív magatartása a hazai feldolgozóiparban. Szociológiai Szemle. 2. 51-70. o.

Csite A.-Kovách I. (1998) Gazdasági elit: útban az osztályhatalomhoz. - Társadalmi Szemle. 4. 16-34. o.

Deák Sz. (2002) A hazai ipari parkok és a betelepült vállalkozások jellemzői (empirikus felmérés). Buzás N.-Lengyel I. (szerk.) Ipari parkok fejlödési lehetöségei: regionális gazdaságfejlesztés, innovációs folyamatok és klaszterek. SZTE GTK, JATEPress, Szeged. 175-200. o.

Domaňsky, H. (2001) A szegénység társadalmi meghatározói a posztkommunista társadalmakban. Szociológiai Szemle. 4. 40-65. o.

Egedy T. (2001) A lakótelepek társadalmi környezetének átalakulása a rendszerváltozâs után. - Földrajzi Értesítő. 1-4. 271-283. o.

Farkas P. (2002) A globalizació és fenyegetései. A világgazdaság és a gazdaságelméletek zavarai. Aula Kiadó, Budapest.

Ferencz Z. (2003) A multinacionális cégek szerepe, megítélése. - Szirmai V.-Csobod É.-Domokos T.Ferencz Z.-Molnár B.-Szépvölgyi Á.-Szilágyi K. Az önkormányzati és lakossági részvételt meghatározó szociológiai elemek, a hulladékgazdálkodási törvény gyakorlati végrehajtása, az ismeretátadás, oktatás szerepe. Kézirat. MTA Szociológiai Kutatóintézet. 78-90. o.

Hegedüs J.-Tosics I. (1998) A közép-kelet-európai lakásrendszerek átalakulása. - Szociológiai Szemle. 2. 5-31. o.

Hay, C.-Marsh, D. (2000) Demystifying Globalization. University of Birmingham, Polsis.

Inotai A. (2001) Gondolatok a globalizációról. - Földes Gy.-Inotai A. (szerk.) A globalizáció kihívásai és Magyarorszäg. Napvilág Kiadó, Budapest. 11-72, o.

Kállay L. (2002) Paradigmaváltás a kisvállalkozás-fejlesztésben. - Közgazdasági Szemle. Júliusaugusztus, 557-573. o.

Kovách I. (1997) Posztszocializmus és polgárosodás. - Szociológiai Szemle. 4. 19-45. o.

Kolosi T.-Szelényi I.-Szelényi Sz.-Western, B. (1991) Politikai mezők a posztkommunista átmenet korszakában. - Szociológiai Szemle. 1. 5-34. o.

Laki M. (2002) A tulajdon müködtetése. A magyar nagyvállalkozók felhalmozott tudásának és kapcsolatainak hasznosítása. - Közgazdasági Szemle. Szeptember, 774-793. o.

Lányi K. (2001) Vázlat a globalizációnak nevezett jelenségkör értelmezéséröl. - Közgazdasági Szemle. Június, 498-519. o.

Lengyel I. (2002) A regionális gazdaság- és vállalkozásfejlesztés alapvetỏ szempontjai. - Buzás N.Lengyel I. (szerk.) Ipari parkok fejlödési lehetöségei: regionális gazdaságfejlesztés, innovációs folyamatok és klaszterek. SZTE GTK, JATEPress, Szeged. 24-54. o.

Leveleki M. (1998) Munkaerőpiaci szereplök Székesfehérvár gépiparában. - Comitatus. Október, 30-36. o.

Leveleki M. (1999) A bérmunka paradicsoma. Mit kínálnak a munkaadók Fejér megyében? - Tér és Társadalom. 1-2. 176-185. o.

Martin, H.P.-Schumann, H. (1998) A globalizáció csapdája. Tamadás a demokrácia és a jólét ellen. Perfekt Kiadó, Budapest.

Makó Cs.-Ellingstad, M. (1999) Globalizáció, közvetlen külföldi tőkebefektetések és a vezetői gyakorlat modernizációja. - Szociológiai Szemle. 4. 40-58. o. 
Molnár B. (2003) Székesfehérvár változó helyzete az európai és a magyar urbanizációs folyamatokban. Az Európai Integráció - A csatlakozás kihivásai. PhD Konferencia, konferencia kötet. KJF, Székesfehérvár.

Molnár L.-Skultéty L. (1999) A beruházások és a gazdaságpolitika. - Cégvezetés. 1. 103-114, o.

Pálmai Z. (2001) Vállalatirányítás a technológiai trendek tükrében. - INCO I.

Sassen, S. (1991) The Global City: New York, London, Tokyo. Princeton, Princeton University Press.

Surányi S. (1999) Globalizálódó világgazdaság - Régi és új kihívások. - Cégvezetés. 1. 85-92. o.

Szántó Z.-Tóth I.J. (2002) Munkanélküliek Fejér megyében. Egy empirikus munkaeröpiaci vizsgálat néhány tanulsága. - Szociológiai Szemle. 1. 4-20. o.

Simonyi Á. (2000) Versenyképesség jóléti rendszer és közjavak révén. - Szociológiai Szemle. 1. 33. o.

Szalai E. (2001) Gazdasági elit és társadalom a magyarországi ủjkapitalizmusban. Aula, Budapest.

Szirmai V. (1994) Budapesti regionális szereplehelöségek és az európai integráció. - Gáthy V. (szerk.) Leltár. Disputa Könyvek. MTA Társadalmi Konfliktusok Kutatóközpontja, Budapest.

Szirmai V.-A. Gergely A.-Baráth G.-Molnár B.-Szépvölgyi Á. (2002) Verseny és/vagy együttmüködés. (A város és környék kapcsolatai). MTA Szociológiai Kutatóintézet - MTA RKK NYUTI Középdunántúli Kutatócsoport, Budapest-Székesfehérvár.

Szirmai V.-Baráth G.-Molnár B.-Szépvölgyi Á. (2001a) Tatabánya és térsége (Tata és Oroszlány) társadalmi és gazdasági kapcsolatrendszerei. Kézirat. MTA Szociológiai Kutatóintézet.

Szirmai V.-Baráth G.-Molnár B.-Szépvölgyi Á. (2001b) Város és vidékének társadalmi, gazdasági kapcsolatrendszerei - A vidéki térségek fenntartható fejlódésének társadalmi lehetőségei. Kézirat. MTA Szociológiai Kutatóintézet.

Szirmai V.-Baráth G.-Molnár B.-Szépvölgyi Á. (2002) A multinacionális vállalatok telephelyválasztási stratégiái. A versenyképesség növelésének tényezöi. Kézirat. MTA RKK NYUTI Közép-dunántúli Kutatócsoport.

Tamás P. (2001) Posztfordizmus és a közép-európai forgatókönyvek. Globalizációs hálózatok és szerepminták. - Földes Gy,-Inotai A. (szerk.) A globalizáció kihívásai és Magyarország. Napvilág Kiadó, Budapest. 73-111. o.

Vilmányi M. (2000) A regionális üzleti hálózatok főbb kérdései. - Farkas B.-Lengyel I. (szerk.) Versenyképesség - regionális versenyképesség. SZTE GKK Közleményei. JATEPress, Szeged. 187-202, o.

Willkinson, R.-Hughes, S. (2002) Global Governance, Critical Perpectives, London, New York.

\section{GLOBALISATION AND REGIONAL DEVELOPMENT}

\section{VIKTÓRIA SZIRMAI - GABRIELLA BARÁTH - BALÁZS MOLNÁR - ÁKOS SZÉPVÖLGYI}

The most successful cities and regions of rapid social and economical transformation in CEE countries could solve their crisis through attracting foreign direct investment that meant the integration to the global economy for them. However, the possible ways of further development seem to be unclear due to the increasing discrepancies of global economy. It means that many well developed subregions and cities are facing with the issue of sustainability. In this way, the possibility to maintain and improve the dynamics of economic and social development became the most actual question.

For this reason, this paper is aimed at describing the concrete local social and economic effects of globalisation. To reach this goal we attempt to analyse local, globalisation based processes through an empirical research in Székesfehérvár. Additionally we try to describe favourable and unfavourable consequences and the role -and it's changing - of upper class in realisation of local globalisation.

In the authors view the ways of avoiding the problems derive from globalisation might be better managed by knowing these processes. 